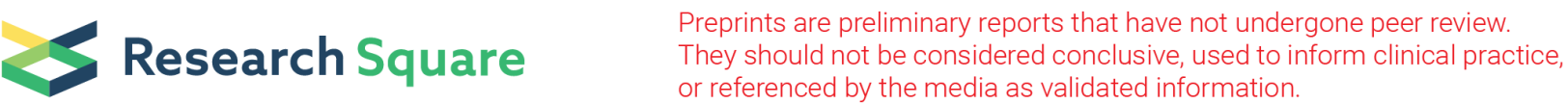

\section{Geochemical monitoring of deionized seawater injected underground during construction of an LPG rock cavern in Namikata, Japan, for the safety water curtain system}

\author{
Akira Ueda ( $\nabla$ akira@sci.u-toyama.ac.jp ) \\ Toyama Daigaku \\ Akiko Ozawa \\ Mitsubishi Materials Techno. Corp. \\ Yasushi Kusakabe \\ Dia Consultant Co. Ltd.

\section{Takafumi Furukawa} \\ Mitsubishi Chemical Corp: Mitsubishi Chemical Kabushiki Kaisha \\ Kohei Yamaguchi \\ Mitsubishi Materials Corp. \\ Masayuki Yageta \\ Mitsubishi Materials Corp.

\section{Takeshi Otake} \\ JOGMEC
}

\section{Research Article}

Keywords: LPG rock cavern, seal water, groundwater, isotope, end-member, flow mode

Posted Date: March 16th, 2021

DOI: https://doi.org/10.21203/rs.3.rs-161509/v1

License: (c) (i) This work is licensed under a Creative Commons Attribution 4.0 International License.

Read Full License

Version of Record: A version of this preprint was published at Environmental Earth Sciences on October 31st, 2021. See the published version at https://doi.org/10.1007/s12665-021-10062-5. 


\section{Abstract}

An underground liquified petroleum gas (LPG) storage facility was constructed between 1998 and 2006 in Namikata, Imabari City, Ehime Prefecture, Japan, to increase domestic LPG stockpiles. The most important issue during construction and operation of this facility is gas leakage prevention. To thwart water leakage, the water curtain system was constructed according to design standards, and a large amount of deionized seawater (seal water) was continuously injected into the rock mass around the cavern to keep the water level constant during both construction and operation. It is possible to distinguish three end member waters (existing groundwater, seawater or fossil seawater, and seal water) using the salinity and isotope $\left(\delta^{18} 0\right)$ difference because seal water injected underground has almost the same $\delta^{18} \mathrm{O}$ value as seawater. In this study, continuous observation is carried out using the geochemical techniques for flow analysis with a mixing ratio of three end members in the initial construction period (April 2005 to March 2006) of the LPG underground storage facility. It is determined that existing groundwater and seawater originally distributed in this region are partly replaced by seal water in the cavern.

\section{Introduction}

Liquified petroleum gas (LPG) is a gaseous fuel that is mainly composed of butane and propane extracted from by-product gases in oil fields, natural gas fields, and oil refineries. It can be easily liquefied at room temperature by simple compressors and cooling. It is transported, stored, and delivered in liquid form. LPG is among the most important energy resources for social and economic prosperity that is widely used as a power source for homes and automobiles (Agency for Natural Resources and Energy, 2017). In addition to storage in aboveground tanks, many methods of storing LPG in underground facilities have been implemented in countries other than Japan. To store LPG safely, the groundwater level and the chemical and isotopic composition must be monitored (Nenoen and Blindheim, 1989; Hamberger, 1991; Kim et al., 2000; Appelo, J. et al., 2003, 2007, 2011; Lee, J.Y., Yamamoto and Pruess, 2004; Eric et al., 2005; Park et al., 2005; Raghavan et al., 2007; Li et al., 2009; Lim et al., 2013; Saikat, Kannan, 2015; Lin et al., 2016). J. Lee et al. (2007) calculated the mixing ratio of seawater and groundwater based on the chlorine $(\mathrm{Cl})$ concentration and oxygen isotopic composition $\left(\delta^{18} \mathrm{O}\right)$ of tunnel spring water. Using tritium and helium isotopes, they analyzed groundwater around an LPG stockpiling location in a coastal area of Korea. Lim et al. (2013) analyzed the flow of groundwater in oil storage depots for which seawater is injected as seal water into the ground. The main components and hydrogen and oxygen isotopic compositions were analyzed to determine the mixing ratio of injected seawater to existing groundwater.

To increase domestic LPG stockpiles, the Japanese government started construction of two underground LPG stockpiling locations in Namikata, Imabari City, Ehime Prefecture, and Kurashiki City, Okayama Prefecture, in 2003 (Fig. 1a). Namikata base construction was started by the National LPG Stockpiling Company, which was established in December 1998 to promote the construction. In 2004, the Japan Oil, Gas and Metals National Corporation (JOGMEC) took over the construction operations through a 
transition of the national stockpiling system. JOGMEC continued construction work on behalf of the national government and completed the project in March 2013. The Namikata base, like the Kurashiki base, is Japan's first underground LPG storage facility that uses a water-sealed rock mass tank. Approximately 450,000 tons of LPG are stored at the base, making it the world's largest LPG storage facility (Otake, 2000; Okazaki et al., 2014; Kurose et al., 2014; JOGMEC, 2000, 2020). Among the important safety measures in the construction of underground LPG storage facilities is preventing LPG leakage into the ground. Because the annual precipitation (1219 mm; Japan Meteorological Agency, 2020 ) in Ehime Prefecture is less than that in other areas in Japan, a large amount of seawater (approx. $1500 \mathrm{~L} / \mathrm{min}$ ) is deionized and continuously injected as seal water into the rock mass around the cavern from the water gallery; this is intended to keep the groundwater level constant during the period of tunnel construction for the storage facility (Fig. 1b). It is important to maintain a safe water-sealing system with injected seal water, and methods such as water-level observation using observation pits that continuously monitor the groundwater table are implemented before and during construction. Monitoring of the injected seal water's underground flow and changes in water quality because of mixing with existing groundwater and seawater is necessary to understand the flow of water around the cavern. The chemical composition of groundwater originally distributed in the Namikata area is similar to that of seal water, with a low salt concentration, and existing groundwater and seal water cannot be distinguished from each other by chemical composition. On the tank's north side, seawater gushes into the tunnel.

The purposes of this study were to identify the contribution ratio of seal water, existing groundwater, and seawater in the tunnel and observation wells and to examine the environmental change in groundwater, which is altered as construction progresses from distribution of these three end-member waters, by paying attention to when the hydrogen and oxygen isotopic compositions of seal water show almost the same deuterium $(\delta D)$ and $\delta^{18} \mathrm{O}$ values as those of seawater. In this study, the hydrogen and oxygen isotopic compositions and $\mathrm{Cl}$ concentration values of water samples were measured monthly during the initial construction period (April 2005 to March 2006), and the main chemical components were analyzed to examine the groundwater behavior geochemically.

\section{Geological Overview Of The Namikata Area}

The Namikata area is located on a peninsula in Imabari City, Ehime Prefecture, facing the Seto Inland Sea (Fig. 1a). The Namikata LPG terminal had already been operating as a ground facility. For underground storage of LPG, three caverns (maximum width of $26 \mathrm{~m}$, height of $30 \mathrm{~m}$, and length of $500 \mathrm{~m}$ ) at elevations from -180 to -150 meters above sea level (mASL), water galleries (-120 mASL), and working tunnels were constructed. The area was largely separated into a Propane cavern area and a Butane/Propane cavern (Fig. 1b). A geological map of the study area is shown in Fig. 2 (modified from Otake, 2000). The study area belongs to the Inner Zone of Southwest Japan, and granite formed in the Mesozoic's Cretaceous period is widely distributed. The main rock is Namikata granite, and Takanawa granodiorite is distributed near the northern coast. Takanawa granodiorite is inferred to be widely distributed under sea surface in northern areas, although its distribution over land areas is small. In the 
northwestern part of the land area, quartz porphyry dikes penetrate the granite, and it is estimated that they are continuously distributed in the northern sea area. Quaternary sediments cover these plutons. Namikata and Takanawa granodiorite exhibit a course, semi-granular structure. The constituent minerals are mainly composed of plagioclase, quartz, and biotite; trace amounts of K-feldspar and amphibole are included; and zircon was observed in Takanawa granodiorite (this study). Plagioclase, which constitutes Namikata granite and Takanawa granodiorite are relatively homogeneous feldspar rich in andesine ( $\mathrm{Na}$; this study). Namikata granite is classified as a weathered part, a weathered-fresh transition part, and a fresh part, according to the degree of weathering. Fresh top elevations range from about $+20 \mathrm{mASL}$ (ridge part) to about - 30 to - $40 \mathrm{mASL}$ (coastal area) and tend to be deeper toward the coast. The fresh rock mass below this depth is composed of an almost-homogeneous rock mass with low permeability, except for some sections. Takanawa granodiorite is distributed from the cavern's northern part to the adjacent site, and it is seen as bedrock similar to Namikata granite. According to outcrop observation, the quartz porphyry has more cracks than both granitic rocks and is estimated to be highly permeable. Crack systems in the Namikata area tend to be relatively steep and run predominately in north-northwest to north-northeast and northwest to east-northeast directions (Otake, 2000).

\section{Sampling And Analytical Procedures}

The sampling points for water samples were spring water points in the working tunnel, the water gallery, the cavern, and the tunnel connecting them (Fig. 3). Water samples from the water-gallery facilities on the ground, the surrounding streams, and observation wells were also collected (Table 1). In this study period, analysis was advanced for the sample water for 1 year, from April 2005 to March 2006. In this period, excavation was completed for the working tunnel and the water gallery. In the cavern, the 30-m height was excavated in five stages, and excavation of the arch section ( $7.5 \mathrm{~m}$ from the top) was in progress.

Spring water in the tunnel was collected monthly in 100-mL polyethylene bottles for isotope analysis (Fig. 3). For major chemical component analysis, samples were collected monthly from April to October 2005, for 7 months, and once every 2 months from November to March 2006 in polyethylene bottles (indicated in red in Fig. 3). Seawater was sampled on May 25 and August 10, 2005. Groundwater from well 15 near the study area was sampled five times between May 2005 and January 2006. At these sampling times, water was pumped upward using an electric pump and sampled from a faucet. Stream water in the study area was sampled on July 12,2005 . Measurements at the time of sampling were water temperature, flow rate, $\mathrm{pH}$, electric conductivity (EC), and oxidation-reduction potential (ORP). The $\mathrm{pH}, \mathrm{EC}$, ORP, and water temperature were measured using a portable $\mathrm{pH} / \mathrm{EC}$ meter (WM-32EP; DKK-TOA) and an ORP meter (RM-12P; DKK-TOA). The flow rate was measured using a measuring cylinder or beaker. For areas from which water could not be sampled by measuring cylinders or beakers because of flow down the wall, the approximate flow rate was determined by measuring part of the flow rate.

Hydrogen and oxygen isotopic compositions and main chemical components were analyzed at the Analysis Center of Mitsubishi Materials Techno Co. The oxygen isotopic composition $\left(\delta^{18} 0\right)$ of the water samples was measured by the $\mathrm{H}_{2} \mathrm{O}-\mathrm{CO}_{2}$ isotope exchange reaction method (Epstein and Mayeda, 1953). 
The Optima Micromass mass spectrometer was used. The analytical precision was $\pm 0.1 \%$ o. The hydrogen isotopic composition ( $\delta \mathrm{D})$ was determined by reacting a water sample of about $3 \mu \mathrm{L}$ with about $1 \mathrm{~g}$ of metallic zinc in a vacuum at $410^{\circ} \mathrm{C}$ for 2 to 5 hours to generate $\mathrm{H}_{2}$ gas (Coleman et al., 1982) and then introducing the hydrogen gas into the mass spectrometer. The analytical precision was $\pm 1 \%$ o

$\mathrm{Na}$ and $\mathrm{K}$ were determined by flame atomic absorption spectrometry (Hitachi Z-8200). Calcium (Ca), magnesium $(\mathrm{Mg})$, aluminum, silicon, boron, iron, and manganese were determined by inductively coupled plasma (ICP) emission spectrometry (7700cx ICP mass spectrometry; Agilent Technologies). Cl and sulfate $\left(\mathrm{SO}_{4}\right)$ were determined by ion chromatography (Metrohm 761 Compact IC). Total carbonate concentration was determined by the acid consumption $(\mathrm{pH} 4.8)$ titration method. The charge balance $($ Err \% $=[($ Scat - San $) /($ Scat + San $)] \times 100$, where Scat and San show total cation and total anion equivalents; Appelo and Postma, 1993) of the main components was within $\pm 5 \%$ in all samples.

\section{Results And Discussion}

The major chemical components and the hydrogen and oxygen isotopic compositions of water samples in the Namikata area are shown in Table 1. The samples in which only the oxygen isotopic compositions and the $\mathrm{Cl}$ concentration values of spring water in the tunnel were analyzed are shown in the supplement data.

\subsection{Hydrogen and oxygen isotopic compositions}

The hydrogen and oxygen isotopic compositions of water samples in this study are shown in Fig. 4. The solid line in the figure shows a global meteoric water line $\left(\delta D=\delta^{18} O+10\right.$; Craig, 1961; Dansgaard, 1964). The water samples showed the composition near the straight-line connecting groundwater in the observation well and seawater. The $\delta D$ and $\delta^{18} 0$ values of the collected seawater were $-7 \%$ ond $0.5 \%$, respectively, which were slightly lower than those of Vienna Standard Mean Ocean Water ( $\delta \mathrm{D}=$ $\delta^{18} \mathrm{O}=0 \%$ ). Because this seawater came from the Seto Inland Sea, seawater in the bay was slightly diluted by surrounding river water or precipitation. Seal water was obtained by desalting the surrounding seawater using the osmotic membrane method, and the EC value was as low as 8.0 to $27.6 \mathrm{mS} / \mathrm{m}$. The $\delta D$ and $\delta^{18} O$ values were $-7 \%$ o to $-8 \%$ ond $-0.8 \%$, respectively, which were slightly lower than those values for seawater (Table 1). The reason for this is unknown, but some isotope fractionation may have occurred during the desalination process.

Water samples, except those from observation well 39, showed lower EC values of 20 to $58 \mathrm{mS} / \mathrm{m}$, $\delta \mathrm{D}$ values of $-54 \%$ o to $-47 \%$, and $\delta^{18}$ o values of $-8.4 \%$ o to $-7.4 \%$ o than those of seal water or seawater (Table 1). River water and groundwater in Ehime Prefecture had $\delta D$ values of $-60 \%$ ond $-42 \%$ and $\delta^{18} \mathrm{O}$ values of $-8.9 \%$ and $-7.1 \%$, respectively (Mizota and Kusakabe, 1994). Groundwater in the study area showed similar values, so it was judged to reflect the average precipitation in this area. The $\delta D$ and $\delta^{18} \mathrm{O}$ values of precipitation are known to vary widely from month to month, but groundwater in this area 
showed almost constant values, suggesting that precipitation infiltrated underground for more than 1 year. The $\delta D$ value of groundwater in well 39 was $-30 \%$ and the $\delta^{18} 0$ value was $-4.4 \%$; these are intermediate values between those of seawater and existing groundwater (Fig. 4). However, because the EC value was $103 \mathrm{mS} / \mathrm{m}$ and the $\mathrm{pH}$ value was extremely high (pH 11.6), it is highly likely that half of the seal water was mixed into existing groundwater and reacted with the cement injected around the tunnel to increase both the EC value and the $\mathrm{pH}$ value. Seal water was used in borehole drilling, and it is possible that it was not replaced by groundwater and instead remained in the mix; however, seal water may have infiltrated to this point. The proportion of seal water was estimated to be around $40 \%$, with the remainder as existing groundwater. The $\delta D$ value of groundwater in well 15 was $-50.6 \%$, which was the $\delta D$ value of existing groundwater in this area.

\subsection{Three end-members in water samples in the tunnel}

The $\delta^{18} \mathrm{O}$ value and $\mathrm{Cl}$ concentration values of the water samples in the tunnel and observation wells are shown in Fig. 5a. Most of these samples were plotted in the area surrounded by three points of seawater, seal water, and existing groundwater. Because there were significant differences in isotopic composition between seal water and groundwater in the study area, and because seawater and seal water have a similar isotopic composition but different salt concentrations ( $\mathrm{Cl}$ concentration and $\mathrm{EC}$ value), these three end-members can be distinguished (Fig. 5a). Assuming that the water samples in the study area were mixed with seal water, existing groundwater, and seawater (water of high salinity north or south) at an arbitrary ratio, the mixing ratio of these three end-members was determined from the $\delta^{18} \mathrm{O}$ value and $\mathrm{Cl}$ concentration value using the following formula. Only $\delta^{18} \mathrm{O}$ was used for the mixing ratio calculation, because as shown in Fig. 4, there was a 1:1 correlation between $\delta^{18} \mathrm{O}$ and $\delta \mathrm{D}$ values; thus, $\delta^{18} \mathrm{O}$ values, which are relatively easy to apply to isotopic composition analysis, were used:

$\mathrm{Cl}=\mathrm{Cl}_{D} \times X_{D}+\mathrm{Cl}_{S} \times X_{S}+\mathrm{Cl}_{G} \times X_{G}(1)$

$\delta^{18} \mathrm{O}=\delta^{18} \mathrm{O}_{D} \times X_{D}+\delta^{18} \mathrm{O}_{S} \times X_{S}+\delta^{18} \mathrm{O}_{G} \times X_{G}(2)$

$X_{D}+X_{S}+X_{G}=1(3)$

where $D, S$, and $G$ denote seal water, seawater, and existing groundwater and $X$ denotes the proportion of each end-member. The settings for the three end-members are shown in Table 2. Considering the analytical error of $\delta^{18} \mathrm{O}$ and $\mathrm{Cl}$ concentration value, the error of the obtained mixing ratio is about $\pm 5 \%$.

As an example of the time variation of the mixing ratio, the results at sample point B-6 of water gallery No. 1 in the Butane/Propane are shown in Fig. 5b. The horizontal axis shows the monthly values for the survey period from March 2005 to February 2006, and the vertical axis shows the percentage of each source water contained in the water sample. At this point, seawater was about $90 \%$, and the remaining water was existing groundwater. However, from July 2005 , as construction progressed, the impact of seal water began to appear, and it can be seen that the proportion of three end-members fluctuated by about $10 \%$ monthly. It can also be seen that although the contribution of seawater decreased relatively, the 
groundwater portion increased slightly. In the Namikata area, oxygen isotope and $\mathrm{Cl}$ concentration analysis for working tunnel, water gallery, carven, and surrounding groundwater and seal water was determined for about 400 samples at 103 sites (Table 1 and supplement data).

\subsubsection{Working tunnel ( 0 to $-125 \mathrm{mASL})$}

At the working-tunnel level (Fig. 5c), several springs were found. Water at sample points T-6 (TD (tunnel distance) $62 \mathrm{~m}$ ), T-7 (TD $270 \mathrm{~m}$ ) in water supply tunnel and T-2 (TD $400 \mathrm{~m}$ ), T-3 (TD $600 \mathrm{~m}$ ), and T-9 (TD $507 \mathrm{~m}$ ) in working tunnel were considered fresh seawater based on their chemical composition (Table 1). These sample points are located in the northeastern part of the water supply tunnel, where fresh seawater gushes out. At sample point T-4 (TD $717 \mathrm{~m})$ and T-8 (TD $710 \mathrm{~m})$, the contribution of groundwater was large, but seawater is mixed in, accounting for around $10 \%$. These springs are transformed into Ca-rich seawater (Table 1), which distinguishes them from the northeastern regions where fresh seawater gushes out. At sample point T-5 (TD $948 \mathrm{~m}$ ), which sample point up on the west side of the working tunnel, seal water replaced $90 \%$ in March and $100 \%$ in April. At point T-1 (TD 250 m), seawater accounts for $20 \%$, groundwater for $70 \%$, and seal water seal for $10 \%$. From the chemical composition, fresh seawater contributes to this seawater component, and it is judged that it is spring water near the seawater/freshwater interface.

\subsubsection{Water gallery (-125 mASL)}

At the water-gallery level (Fig. 5d), the source water mixing ratio greatly changed with time, depending on the gushing point. A major feature was the large contribution of seawater to the tunnel's north side. In the southern part, the water from sample points P-16 (TD $917 \mathrm{~m}$ ) and P-15 (TD $937 \mathrm{~m}$ ) from the investigation hole was judged to be a Ca-rich fossil seawater type (Table 1). Existing groundwater with $100 \%$ of the water sample in the tunnel could be identified only at the following four locations: sample point B-1 (TD $63 \mathrm{~m}$ ) in the Butane/Propane water gallery No. 1, sample point B-45 (TD $467 \mathrm{~m}$ ) in Butane/Propane water gallery No. 2, sample point P-97 (TD $68 \mathrm{~m}$ ) in Propane water gallery No. 2, and sample point P-20 (TD 97 $\mathrm{m}$ ) in Propane water gallery No. 3 (Fig. $5 \mathrm{~d}$ ). In addition, a range of mixed water was found in the horizontal tunnel (sample point P-58). Such water was distributed to the south and was considered to correspond to areas with high groundwater potential. As for seal water, it made up $100 \%$ of the contribution in the central zone in the water gallery, but in other places, it was mixed with water of another origin.

The mixing ratio of each end-member in water gallery as of February 2006 is shown in Fig. 6a. The black circles in the figure represent measurement points, and the other sections are interpolated data. This figure also shows that seawater (or fossil seawater) was distributed to the north and south, as mentioned previously, and that more water gushed out on the Butane/Propane side. A considerable amount of groundwater flowed out not only to the south but also to the north.

\subsubsection{Cavern (- $150 \mathrm{mASL})$}


At the cavern level, it was difficult to track long-term changes because many sites were unable to collect spring water due to the progress of excavation work, and also because the source site was changed. The inflow of water into Carven, compared to the water gallery tunnel, indicates that the seal water is flowing out predominantly, replacing existing groundwater and seawater (Fig. 5e). The mixing ratio of each endmember in carven as of February 2006 is shown in Fig. 6b. Seawater springs in the northeastern region account for less than $20 \%$ of spring water, but they still spring out. Similarly, the proportion of groundwater has not fluctuated significantly during the study period but has emerged in the southeast and northwest regions.

\subsubsection{Change in proportion of three end-members in water samples from April to December 2005}

Figure 7 compares the results of change of the proportion of end-members in water samples at the watergallery level between April and December 2005. In Fig. 7, the red and blue areas indicate an increase and a decrease in the end-members' contribution to the water samples in December compared with April 2005. The line in the figure also shows the difference between April and December in the observation well's water level. If this value is negative, it means that the water level was slightly lower than in April. The results show that seawater increased in the south and north during the eight months. This was considered the effect of increasing the pressure of seal water at the south side during this period. The amount of spring water originating from seawater decreased in the north, which is in harmony with the ratio of seal water. Therefore, the amount of seawater decreased because of the increase of seal water.

\subsection{Chemical composition}

The Stiff diagram (Stiff, 1951) in Fig. 8 shows water samples in the study area indicating that the water samples are mixture of seawater, seal water and groundwater. The relationship between each chemical component and the $\mathrm{Cl}$ concentration are shown in Fig. 9. The broken line in Fig. 9 shows a simple mixing of seawater and seal water or groundwater. There was no significant chemical difference in water sample from the Butane/Propane and Propane areas. $\mathrm{Na}, \mathrm{Mg}$ and $\mathrm{SO}_{4}$ ions are plotted near this simple mixing line or show slightly lower values (Fig. 9). $\mathrm{K}$ ion for most samples except for those in working tunnel were clearly lower than the line. In contrast, $\mathrm{Ca}$ and $\mathrm{HCO}_{3}$ ions were quite higher than the mixing line. These results suggested that the saline spring waters in the tunnel are of current sea water in some places and the fossil sea water rich in Ca components in other places.

p>The Piper diagram (Piper, 1944) of the water samples is shown in Fig. 10. In the northern part of a working tunnel, the water was characterized by its high salt concentration, and two water samples (T-7 and (-9) in working tunnel had a $\mathrm{Cl}$ concentration value almost equal that of current seawater (Fig. 10a). At sample point $\mathrm{T}-1$, the spring water consisted of $10 \%$ seal water, nearly $70 \%$ groundwater, and the remainder was sea water (Fig. 5c), which was judged to be current sea water (Fig. 10a). On the other hand, T-4 and T-7 are spring waters in which more than $90 \%$ of the ground water is mixed with about 10 $\%$ of the sea water, but because of their Ca-rich composition, this sea water is highly likely to be fossil sea 
water. That is, sea water was altered to the $\mathrm{Na} \cdot \mathrm{Ca}-\mathrm{Cl}$ type. Lee, J. et al. (2007) reported that a major chemical composition analysis and hydrogen and oxygen isotopic compositions of groundwater at an LPG stockpiling base constructed in the coastal area of South Korea resulted in mixing of seawater and existing groundwater. Most spring waters in the tunnels were plotted far away from the 1:1 line of sea water and groundwater mixing line except bromide. They discussed using a principal component analysis and showed that cations in the ground water such as $\mathrm{Ca}, \mathrm{Na}, \mathrm{Mg}$, and $\mathrm{K}$ are irregularly enriched or depleted by various hydrogeochemical reactions between host rock and the ground water along the flow path. In general, seawater that changes its water quality by reacting with rocks is called fossil seawater and has been reported worldwide (e.g., Meyers, 1968; Capuano, 1990, 1992). Fossil seawater has also been reported in many places in Japan (e.g., Sakai and Matsubaya, 1974; Mizukami et al., 1977; Ueda et al., 2010; Okano et al., 2020).

In water gallery, there are many types of spring waters were gushing out. As same as the working tunnel, there are saline spring waters in the northeastern part (Fig. 10b). Water sample at B-15, $100 \%$ current sea water gushes out from the chemical composition, and at P-59, sea water was diluted with seal water (Fig. 5d). Other spring waters with high salt concentration are considered to be formed by the dilution of fossil seawater into groundwater or sea water at various rates. In the water gallery, $100 \%$ of the groundwater is gushed out at B-1 and P-20 and its water quality is $\mathrm{Ca}-\mathrm{HCO}_{3}$ type. Other spring waters (< $10 \mathrm{meq} / \mathrm{L}$ ) are mixture of the seal water and groundwater and show Na-Cl type (Fig. 10b). At sites P-15 and P-16 of the south investigation tunnel in the water gallery, a mixture of groundwater and fossil sea water.

The chemical composition of spring waters in carven were analyzed for 1 and 5 samples in the Propane No. 1 and No. 2 carven, respectively, and other two spring waters (P-69, B-43) from connecting tunnels nearby the Propane No. 2 and Buran/Propane carven were also analyzed (Fig. 10c). Spring waters (P-42, $P-53, P-81)$ in the central part of the carven are dominant in the seal water with small amount of groundwater, and in the northern part (B-43, P-114, P-49) and point P-95 of the No. 1 Propane carven are judged that fossil sea water is diluted with seal water and groundwater. In the northwest part of the No. 2 Propane carven, water samples (P-114, P-115) are adjacent springs, and the former is a dilution of fossil seawater, while the latter is mostly seal water. Thus, it can be seen that the quality of spring water is different even in areas that are only a few meters away.

Groundwater in 13 observation wells was sampled in May 2005 (blue) and November 2005 (green) (Fig. 10d). In wells 7, 10, 25, and 40, groundwater was analyzed at different depths. Most chemical components for groundwaters in the wells remained almost constant at different depth. Groundwater in the observation wells except for well No. 29 was weakly acidic to weakly alkaline, with a pH of 6.0 to 8.8 , and the EC value was $60 \mathrm{mS} / \mathrm{m}$ or less (most samples contained approx. $30 \mathrm{mS} / \mathrm{m}$ ). This is similar to the EC value of the water sample from sample point B-1 in the Butane/Propane water gallery (TD $63 \mathrm{~m}$ ), which was considered to contain $100 \%$ existing groundwater (31 to $43 \mathrm{mS} / \mathrm{m}$ ) (Figs. $5 \mathrm{~d}$ and 10b). From the $\delta \mathrm{D}$ and $\delta^{18} \mathrm{O}$ values of water samples in the observation wells, groundwater in this area showed almost constant values, suggesting that precipitation infiltrated underground for more than 1 year 
(Fig. 4). The chemical composition of the water samples shows the $\mathrm{Ca}-\mathrm{HCO}_{3}$ type and the $\mathrm{EC}$ value is high in a part, but the relation with the geology has not been found. These results indicated that seal water did not infiltrate into these wells. In well 39, water sample showed the intermediate values between seawater and groundwater and the proportion of seal water was estimated to be around $40 \%$ (Fig. 4). The $\mathrm{pH}$ value was extremely high $(\mathrm{pH}$ 11.6). Seal water was used in the borehole drilling and mixed with existing groundwater and reacted with the cement.

\subsection{Behavior of seal water injected into the LPG carven}

In the Namikata LPG carven, a large amount $(1500 \mathrm{~L} / \mathrm{min})$ of seal water (deionized sea water) had been continuously injected into ground. From the isotopic composition and main chemical composition of water samples gushing in the tunnels, three types of source water gushed out in the water gallery and cavern. The source water was sea water or Ca-rich seawater (fossil seawater), existing groundwater, and seal water. In the center part of the tunnel, only seal water gushed but in other areas, spring waters in the tunnels are mixture of three end-members. Saline groundwater spouted in the north and south portions of the water gallery. Groundwater mainly distributes in the southwestern part in the tunnels because water potential is high due to high altitude on the surface (Fig. 8a). Seal water is infiltrating into the main part of the water galleys (Fig. 5b). The groundwater and sea water initially distributed in this area cannot be completely replaced by seal water. Also, sea water-groundwater interface has not been largely changed.

\section{Conclusions}

In the underground LPG storage base constructed in Namikata, a large amount of seal water (deionized seawater) is continuously charged around the cavern to keep the water level constant. The $\delta^{18} \mathrm{O}$ value of seal water is almost the same as that of seawater, but the salinity is different. The proportion of three end-members (seal water, sea water, and groundwater) can be estimated using the $\delta^{18} \mathrm{O}$ value and $\mathrm{Cl}$ concentration of the water samples. To monitor the distribution of seal water, water samples in the tunnels and observation wells are collected monthly. The main chemical components and hydrogen and oxygen isotopic compositions are measured for 1 year from April 2005, and the secular change of the three end-members in water samples at each site are examined. These results show that existing groundwater and seawater before the construction were not completely replaced by seal water. With increasing injected water pressure, the fraction of seal water increases and will be expected to be almost $100 \%$ when the water pressure is $1.3 \mathrm{MPa}$ as the designed value. This study is a one-year observation of spring water, and it is expected that the proportion of seal water into each spring will increase but it is estimated that the position of the boundary between sea water/groundwater or seal water will not change much.

\section{Declarations}

\section{Acknowledgments}


This study was carried out as a part of the investigation of JOGMEC project in the Namikata LPG cavern excavation. We would like to express our gratitude to the JOGMEC members for their cooperation, advice, and opinions regarding this survey. We would like to express our gratitude to the members of the Energy Business Center of Mitsubishi Materials Corporation, the Energy Business Division of Mitsubishi Materials Techno Corporation, and the Namikata Construction Management JV Office, in particular, to S. Ueda, Y. Nakamura, and K. Tanaka for their advice and cooperation in sampling, analysis, and result analysis. We also extend our appreciation to Enago (www.enago.jp) for the English language review.

\section{References}

Agency for Natural Resources and Energy, 2017. Energy supply and demand results. 45 p. (in Japanese)

Appelo, C.A.J., Postma, D., 1993. Geochemistry, groundwater and pollution. ed. by Appelo, C.A.J. and Postma, D., Rotterdam, Brookfield: Balkema. xvi+536.

Capuano, R. M., 1990. Hydrochemical constraints on fluid-mineral equilibria during compaction diagenesis of kerogen-rich geopressured sediments. Geochim. Cosmochim. Acta, 54, 1283-1299.

Capuano, R. M., 1992. The temperature dependence of hydrogen isotope fractionation between clay minerals and water: Evidence from a geopressured system. Geochim. Cosmochim. Acta, 56, 2547-2554.

Coleman, M.L., Shepherd, T.J., Durham, J.J., Rouse, J.E., Moore, G.R., 1982. Reduction of water with zinc for hydrogen isotope analysis. Anal. Chem., 54, 993-995.

Craig, H., 1961. Standard for reporting concentrations of deuterium and oxygen-18 in natural waters. Science, $133,1833-1834$.

Dansgaard, W., 1964. Stable isotopes in precipitation. Tellus, 16, 436-438.

Eric, A., François, C., Anne, M., 2005. Groundwater management during the construction of underground hydrocarbon storage in rock caverns. 9th International Mine Water Congress.

Epstein, S., Mayeda, T., 1953. Variation of 018 content of waters from natural sources. Geochim. Cosmochim. Act, 4, 213-224.

JOGMEC, 2000. 'The first LPG cavern in Japan', Oil and Natural Gas Review, JOGMEC edited by Yamada, $\mathrm{M}, 125-137$.

JOGMEC, 2020. 'Namikata national LPG stockpiling base', http://www.jogmec.go.jp/about/domestic_008-04.html.

Hamberger, U., 1991. Case history: Blowout at an LPG storage cavern in Sweden. Tunnelling Undergr. Space Technol., 6, 119-120. https://doi.org/10.1016/0886-7798(91)90012-S. 
Japan Meteorological Agency, 2020. Average amount of precipitation at Imabari.

http://www.data.jma.go.jp/obd/stats/etrn/view/nml_amd_ym.php?

prec_no $=73 \&$ block_no $=1077 \&$ year $=\&$ month $=\& d a y=\& v i e w=$.

Kim, T., Lee, K.-K., Ko, K.S., Chang, H.W., 2000. Groundwater flow system inferred from hydraulic stresses and heads at an underground LPG storage cavern site. J. Hydrol., 236, 165-184.

https://doi.org/10.1016/S0022-1694(00)00284-5.

Kurose, H., Ikeya, S., Chang, C.-S., Maejima, T., Shimaya, S., Tanaka, T., Aoki, K., 2014. Construction of Namikata underground LPG storage cavern in Japan. Int. J. JCRM, 10, 15-24.

Lee, J., Kim, R.H., Chang, H.W., 2003. Interaction between groundwater quality and hydraulic head in an area around an underground LPG storage cavern, Korea. Environ. Geol., 43, 901-912.

Lee, J., Kim, J.H., Kim, H.W., Chang, H.W., 2007. Statistical approach to determine the salinized ground water flow path and hydrogeochemical features around the underground LPG cavern, Korea. Hydrol. Process., 21, 3615-3626.

Lee, J., Jung, B., Kim, J.M., Ko, K.S., Chang, H.W., 2011. Determination of groundwater flow regimes in underground storage caverns using tritium and helium isotopes. Environ. Earth Sci., 63, 763-770. https://doi.org/10.1007/s12665-010-0747-4.

Lee, J.Y., Cho, B.W., 2008. Submarine groundwater discharge into the coast revealed by water chemistry of man-made undersea liquefied petroleum gas cavern. J. Hydrol., 360, 195-206.

Li, Z., Wang, K., Wang, A., Liu, H., 2009. Experimental study of water curtain performance for gas storage in an underground cavern. J. Rock Mech. Geotech. Eng., 1, 89-96.

https://doi.org/10.3724/SP.J.1235.2009.00089.

Lim, J.-W., Lee, E., Moon, H.S., Lee, K.-K., 2013. Integrated investigation of seawater intrusion around oil storage caverns in a coastal fractured aquifer using hydrogeochemical and isotopic data. J. Hydrol., 486, 202-210. https://doi.org/10.1016/j.jhydrol.2013.01.023.

Lin, F., Ren, F., Luan, H., Ma, G., Chen, S., 2016. Effectiveness analysis of water-sealing for underground LPG storage. Tunnelling Undergr. Space Technol., 51, 270-290.

http://doi.org/10.1016/j.tust.2015.10.039.10.039.

Meyers, J. D., 1968. Differential pressures, a trapping mechanism in Gulf Coast oil and gas fields. Gulf Coast Assoc. Geol. Soc. Trans. 18, 56-80.

Mizota, C., Kusakabe, M., 1994. Spatial distribution of $\delta D-\delta 180$ values of surface and shallow groundwaters from Japan, south Korea and east China. Geochem. J., 28, 387-410. 
Mizukami, M., Sakai, H., Matsubaya, O., 1977. Na-Ca-Cl-SO4-type submarine formation waters at the Seikan undersea tunnel, Japan. chemical and isotopic documentation and its interpretation. Geochim. Cosmochim. Acta, 41, 1201-1212.

Neomoen, B., Blindheim, O.T., 1989. Ground water maintenance and leakage control during construction of unlined rock caverns for pressurized gas storage, Mongstad. Storage of gases in rock caverns. ed. by Nilsen and Olsen and Balkema and Rotterdam, ISBN 90-6191-8960.

Okano, O., Konishi, A., Kita, A., Ueda, A., 2020. Geochemical study for utilization of groundwater heat by open heat pump system in northern Okayama and Akaiwa city areas with low precipitation in Japan. Groundwater Sustain. Dev. https://doi.org/10.1016/j.gsd.2020.100494.

Okazaki, Y., Kaneto, T., Maejima, T., Kobayashi, S., Miyajima, Y., Aoki, K., 2014. Groundwater management for hydraulic containment type underground LPG storage cavern excavation with the observational grouting method. Int. J. JCRM, 10, 25-31.

Otake, K., 2000. Japan's first sealed underground storage system for LPG - Namikata, Ehime Prefecture. Oil and Natural Gas Review, 00囚6, 125-137. (in Japanese).

Park, J.J., Jeon, S., Chung, Y.S., 2005. Design of Pyongtaek LPG storage terminal underneath Lake Namyang: A case study. Tunnelling Undergr. Space Technol., 20, 463-478.

Piper, A.M., 1944. A graphic procedure in the geochemical interpretation of water-analyses. Trans. AGU, $25,914-928$.

Raghavan, N., Kosuri, S.R.K.V., Bhaskar, K.V., de Laguerie, P.d.e., Roux, P., Vaskou, P., Saint, A., 2007. Visakhapatnam underground LPG storage cavern, India. Proceedings of the Institution of Civil Engineers Energy. Proc. Institute Civil Engineers, 160, 79-86.

Saikat, P., Kannan, G., 2015. Ground water management for large under-ground storage caverns. IAEGAGMEP2014, 034. https://doi.org/10.1007/978-3-319-09060-3_167.

Sakai, H., Matsubaya, O., 1974. Isotopic geochemistry of the thermal waters of Japan and its bearing on the Kuroko ore solutions. Econ. Geol., 69, 974-991.

Stiff, H.A. Jr., 1951. The interpretation of chemical water analysis by means of patterns. J. Petrol. Technol., 3, 15-16.

Ueda, A., Nagao, K., Shibata, T., Suzuki, T., 2010. Stable and noble gas isotopic study of thermal and groundwaters in Northwestern Hokkaido, Japan and the occurrence of geopressured fluids. Geochem. J., $44,545-560$.

Yamamoto, H., Pruess, K., 2004. Numerical simulations of leakage from underground LPG Storage Caverns. Environ. Sci. Lawrence Berkeley Natl Lab. LBNL, 56175. https://doi.org/10.2172/836402. 
Table 1 Isotopic and chemical compositions of water samples in tunnels and observation wells.

\begin{tabular}{|c|c|c|c|c|c|c|c|c|c|c|c|c|c|c|c|c|c|c|c|c|}
\hline Sunple Nes & $\begin{array}{l}\text { Semple beulisy } \\
\text { (TD m) }\end{array}$ & Dase & 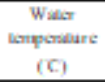 & PH & $\begin{array}{c}\mathrm{FC} \\
(\mathrm{Sm})\end{array}$ & $\begin{array}{l}\text { ONP } \\
(\mathrm{mV})\end{array}$ & iD & $3^{1150}$ & $\mathrm{Na}$ & $\mathrm{K}$ & $\mathrm{Ca}$ & Me & Ca & $\mathrm{SO}_{4}$ & $\mathrm{BCO}_{3}$ & $\mathrm{SO}_{2}$ & B & All & $\mathrm{Fe}$ & Mh \\
\hline \multicolumn{21}{|l|}{$\overline{\text { Dothe } a x x}$} \\
\hline \multicolumn{21}{|c|}{ 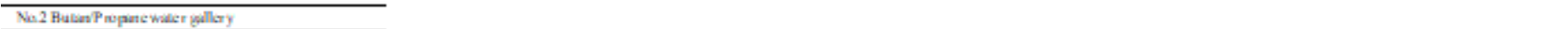 } \\
\hline B-9 & 310 & $2006: 0 \mathrm{~L} / \mathrm{19}$ & 14.7 & 781 & 0.040 & 328 & 35 & -5.0 & 47 & 2 & 34 & 0 & 85 & 12 & 31 & 14 & 0.38 & -0.1 & $=0001$ & $=0001$ \\
\hline \multirow{10}{*}{$\mathrm{H}-10$} & \multirow{10}{*}{278} & 2005,0418 & 19.1 & 8.17 & 0.051 & 216 & .22 & -3.1 & 70 & 3 & 26 & 1 & 120 & 14 & 29 & 8 & 0.78 & $=0.1$ & 003 & $=0001$ \\
\hline & & $2005 / 05 / 24$ & 19.3 & 8.45 & 0.061 & 102 & .25 & -3.6 & 68 & 3 & 2.3 & 1 & 110 & 17 & 34 & 9 & an & $=0.1$ & & 0.020 \\
\hline & & $2005 / 0615$ & 19.7 & 8.34 & 0.049 & 196 & .27 & 4.1 & 67 & 3 & 25 & 1 & 110 & 19 & 33 & 12 & 0.72 & $=0.1$ & 0.22 & -0001 \\
\hline & & $2005 \times 0712$ & 20.0 & 8.26 & 0.053 & 232 & .28 & 45 & 58 & 3 & 25 & 2 & 94 & 20 & 31 & 10 & 0.61 & a.12 & 006 & 0.002 \\
\hline & & 2005 .08 to & 21.0 & 8.49 & 0.048 & 291 & .29 & 4.4 & 62 & 3 & 27 & 2 & 120 & 22 & 29 & 10 & 0.68 & 0.14 & 000 & -0001 \\
\hline & & $2005: 0 \times 13$ & 20.5 & 8.44 & 0.053 & 260 & .28 & 4.1 & $\pi$ & 3 & 26 & t & 120 & 19 & 33 & 9 & a.s & -0.1 & 000 & $=0001$ \\
\hline & & $2005 / 1014$ & 20.2 & 8.40 & 0.052 & 251 & .28 & 43 & 75 & 3 & 29 & 2 & 120 & 18 & 31 & 11 & 0.75 & -0.1 & 000 & -0001 \\
\hline & & $2005 / 1$ L/4 & 19.5 & 8.23 & 0.048 & 278 & 31 & 4.7 & 64 & 3 & 26 & I & 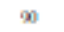 & 22 & 34 & 11 & 0.55 & $=0.1$ & 000 & $=0001$ \\
\hline & & $2006.0 \mathrm{~L} / \mathrm{l}$ & 18.1 & 8.59 & 0.058 & 142 & 31 & 4.4 & 63 & 3 & 30 & 2 & 95 & 21 & 33 & 12 & 0.56 & -0.1 & 000 & $=0001$ \\
\hline & & $2006 / 03 / 06$ & 17.3 & 8.31 & 0.039 & 209 & -31 & 5.0 & 49 & 3 & 25 & 1 & $n$ & 20 & 34 & 10 & 0.40 & $=0.1$ & 001 & -0001 \\
\hline \multirow{3}{*}{ B- -21} & & $2005 / 1 \mathrm{~L} / 4$ & 20.0 & 7.43 & 1.402 & 150 & 39 & .5 .9 & 1200 & 11 & 1700 & $\$ 6$ & 4600 & 420 & 25 & 11 & 003 & $=0.1$ & 0.16 & 0.44 \\
\hline & 116 & $2006.0 \mathrm{~L} / \mathrm{18}$ & 18.3 & 762 & 1.307 & 89 & 42 & 6.0 & 1100 & 21 & 1800 & 85 & 4400 & 440 & 26 & 13 & 004 & -0.1 & 0.12 & 0.38 \\
\hline & & $2006.03 / 06$ & 17.6 & 7.51 & 1.210 & 128 & 40 & 6.5 & 1100 & 13 & 1600 & 82 & 4000 & 390 & 26 & 18 & 004 & $\infty .1$ & 006 & 0.34 \\
\hline & & $2005 / 1 \mathrm{~L} / \mathrm{L}$ & 19.9 & 728 & 2.340 & 140 & 33 & 4.7 & 2100 & 23 & 3000 & 210 & 8000 & 760 & 32 & 13 & 0.14 & -0.1 & 000 & 085 \\
\hline B- -23 & 84 & $2006: 0 \mathrm{~L} / 18$ & 18.6 & 7.37 & 2.500 & 98 & .35 & 4.9 & 2200 & 45 & 3500 & 290 & 8900 & 8.30 & 32 & 13 & $a 12$ & $=0.1$ & $=0001$ & 089 \\
\hline & & $2006 / 03 / 06$ & 18.2 & 736 & 2.700 & 94 & -33 & -5.1 & 2100 & 35 & 3200 & 230 & 8500 & 750 & 29 & 15 & a.13 & $=0.1$ & 005 & 084 \\
\hline B-24 & 66 & $2005 / 1 \mathrm{~L} / 4$ & 20.5 & 722 & 0.326 & 220 & $g$ & -1.3 & 250 & 7 & 390 & 15 & 940 & 43 & 15 & 9 & 0.74 & $=0.1$ & 0.10 & 0.097 \\
\hline 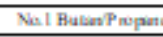 & & & & & & & & & & & & & & & & & & & & \\
\hline & & 2005,0418 & 18.5 & 783 & 0.060 & 226 & -5 & 0.7 & 100 & 5 & 8 & 2 & 170 & 5 & 16 & 8 & 1.40 & -0.1 & 004 & $=0001$ \\
\hline $\mathrm{B}-2$ & 276 & $2005 / 05 / 24$ & 18.9 & 8.66 & 0.062 & 152 & 4 & 0.5 & 110 & 5 & 7 & 2 & 170 & 4 & 14 & 1 & 1.40 & -0.1 & & -0001 \\
\hline & & $2005 / 08$ to & 22.5 & 805 & 0.065 & 338 & -6 & 0.7 & 110 & 5 & 6 & 2 & 190 & 5 & 17 & 1 & L.50 & & 000 & $=0001$ \\
\hline & & 2005.06 is & 20.8 & 7.56 & 0.240 & 103 & $\rightarrow$ & -1.3 & 210 & 6 & 210 & 13 & 700 & 45 & 11 & 2 & L.30 & $=0.1$ & 0.02 & 0.092 \\
\hline H-4 & 180 & $2006.03 / 06$ & 18.1 & 722 & 0.156 & 214 & -12 & -1.9 & 150 & 5 & 130 & 8 & 470 & 31 & 17 & 2 & 0.66 & $=0.1$ & 001 & 0.003 \\
\hline & & 2005/06 I5 & 20.0 & 746 & 1.686 & 2.3 & -36 & -5.5 & 2400 & 34 & 1000 & 230 & 5400 & 850 & 75 & 14 & 0.84 & $=0.1$ & 0.19 & 0.110 \\
\hline & & $2005 / 0712$ & 20.6 & 703 & 1.665 & 14 & 39 & -5.6 & 2400 & 31 & 930 & 200 & 5300 & 880 & 74 & 13 & 0.76 & -0.1 & 006 & 084 \\
\hline & & 2005 .08 10 & 21.4 & 7.40 & 1.645 & 189 & 38 & 5.7 & 2300 & з & 8.50 & 210 & 5300 & 860 & $\pi$ & 14 & 084 & & 000 & 0.78 \\
\hline B-7 & 108 & $2005 / 10 / 4$ & 21.1 & 767 & 1.43 & 235 & 40 & 5.9 & 2200 & 23 & 8.30 & 200 & 4600 & 740 & 71 & 14 & 0.58 & -0.1 & 008 & 074 \\
\hline & & $2005 / \mathrm{L} / 4$ & 19.8 & 774 & 1.40 & 182 & 39 & 6.0 & 2000 & 23 & 920 & 200 & $4+00$ & 720 & 68 & 20 & a.5. & & 003 & 081 \\
\hline & & $2006,0 \mathrm{~L} / 18$ & 17.6 & 774 & 1.886 & 197 & 40 & 5.9 & 2100 & 38 & 1200 & 200 & 5200 & 800 & 72 & 14 & 0.49 & & 0.02 & 090 \\
\hline & & $2006,03 / 06$ & 17.6 & 761 & 1.651 & 175 & -38 & -5.8 & 2000 & 40 & 1300 & 290 & 5400 & 790 & 68 & 16 & 0.43 & $=0.1$ & 001 & 1.10 \\
\hline B-44 & 42 & $2006.01 / 18$ & 15.4 & 7.55 & 3.240 & 293 & 8 & 0.8 & 7000 & 200 & 2700 & 790 & 15000 & 2400 & 58 & 13 & 0.78 & -0.1 & 0.16 & 0.078 \\
\hline & & $2006: 0 \mathrm{~L} / 18$ & 16.5 & 7.43 & 2.620 & 198 & -14 & -1.9 & 2500 & 60 & 3700 & 20 & 9500 & 820 & 22 & 13 & 0.42 & -0.1 & 003 & 0.800 \\
\hline B-6 & 4 & 2006:03/06 & 17.0 & 744 & 2.590 & 165 & -14 & -2.0 & 2200 & 65 & 3900 & 290 & 8800 & 720 & 22 & 10 & 0.41 & $=0.1$ & 002 & 0.000 \\
\hline Briexch bimel (Hus: & & & & & & & & & & & & & & & & & & & & \\
\hline & & $20054 / 18$ & 18.8 & 760 & 0.092 & 240 & 53 & 8.0 & 24 & 3 & 36 & 2 & $3 t$ & 32 & 57 & 18 & $=0.1$ & $=0.1$ & 004 & -0001 \\
\hline & & $2005 / 10 / 14^{*}$ & 21.8 & 785 & 0.090 & 289 & 53 & -8.0 & 25 & 2 & 37 & 3 & 30 & 30 & 56 & 19 & 002 & -0.1 & -0001 & -0001 \\
\hline B-1 & 63 & $2005 / 1 / 14$ & 20.4 & 763 & 0.031 & 321 & -52 & -7.9 & 24 & 2 & 34 & 2 & 28 & 32 & 49 & 20 & $=002$ & & 000 & -0001 \\
\hline & & $20061 / 19 *$ & 18.2 & 8.13 & 0.094 & 184 & -52 & 8.1 & 25 & 3 & 37 & 2 & 31 & 31 & 55 & 19 & $=002$ & $=0.1$ & $=0001$ & -0001 \\
\hline & & $2006: 03 / 06$ & 17.2 & 790 & 0.091 & 531 & -54 & 8.1 & 24 & 3 & 35 & 2 & 36 & 32 & 54 & 18 & $=002$ & $=0.1$ & 000 & -00001 \\
\hline & & $2006: 04 / 19$ & 17.5 & 684 & 3.840 & 180 & -32 & 4.2 & 2800 & 28 & $\$ 00$ & 390 & 15000 & 1100 & 12 & ut & 003 & -0.1 & 008 & 1.1 \\
\hline B-16 & 76 & $2006: 03 / 06$ & 17.4 & 7.10 & 3.860 & 136 & 31 & 4.2 & 2900 & 41 & 6400 & 340 & 15000 & 1100 & 14 & 17 & 004 & -0.1 & 007 & 1.1 \\
\hline B-4? & 60 & $2006: 03 / 06$ & 17.7 & 754 & 4.880 & 95 & 6 & 0.7 & 9000 & 64 & 2100 & 100 & 19000 & 2500 & 99 & 14 & L60 & $=0.1$ & $=0001$ & 0.34 \\
\hline & & $2005 / 05 / 24$ & 19.1 & 708 & 4.700 & 93 & 8 & 0.6 & 9000 & 58 & 1700 & 1200 & 19000 & 2500 & 104 & 14 & 260 & $=0.1$ & & 4.3 \\
\hline & & $2005 / 0615$ & 20.0 & 7.14 & 4.10 & 53 & -6 & 0.6 & 9000 & 59 & 1700 & 1 too & 19000 & 2600 & 89 & 13 & 280 & -0.1 & 0.10 & 0.086 \\
\hline & & $2005: 0712$ & 20.8 & 6.53 & 4.860 & so & -7 & 0.7 & 9200 & 59 & 1500 & 1 too & 18000 & 2600 & 45 & 13 & 270 & $=0.1$ & 007 & 36 \\
\hline & & $2005 / 08$ to & 21.0 & 690 & 4.00 & 115 & -7 & -0.6 & 9000 & 59 & 1300 & 100 & 18000 & 2600 & 95 & 13 & 3.20 & & 002 & 40 \\
\hline B-15 & 37 & $2005 / 0 X 13$ & 21.1 & 702 & 4.00 & 75 & 6 & 0.7 & 9100 & 58 & 1400 & 100 & 18000 & 2600 & 89 & 12 & 340 & & 007 & 29 \\
\hline & & $2005 / 1014$ & 20.3 & 703 & 4.860 & 180 & 8 & 0.8 & 9500 & 44 & 1500 & 100 & 18000 & 2600 & 88 & 14 & 310 & & 0.12 & 32 \\
\hline & & $2005 / 1 \mathrm{~V} / 14$ & 19.3 & 7.12 & 4.870 & 182 & -7 & 0.5 & 9400 & 45 & 1600 & 1200 & 17000 & 2600 & 22 & 14 & L.90 & & 004 & 4.3 \\
\hline & & $2006.0 \mathrm{~L} / \mathrm{18}$ & 18.1 & 7.17 & 4.880 & 224 & -6 & 0.5 & 9600 & 61 & 1600 & 1200 & 18000 & 2700 & 96 & 14 & 280 & & 003 & 34 \\
\hline & & $2006,03 / 06$ & 17.7 & 721 & 4.860 & 157 & -8 & 0.6 & 9500 & 38 & 1400 & 1200 & 18000 & 2600 & 91 & 20 & 260 & -0.1 & 001 & 30 \\
\hline B-43 & 65 & $2006 / 03 / 07$ & 17.2 & 8.68 & 0.667 & 267 & -11 & -1.4 & 560 & 10 & 830 & 26 & 2000 & 410 & 14 & 10 & 0.62 & $=0.1$ & 002 & 0.001 \\
\hline Prqpau navtion & & & & & & & & & & & & & & & & & & & & \\
\hline $\mathrm{Nan} 2$ Propute wilder & & & & & & & & & & & & & & & & & & & & \\
\hline$P-97$ & 68 & $20061 / 19+$ & 17.1 & 1025 & 0.092 & 123 & -54 & -8.0 & 28 & 6 & 26 & 0 & $2)$ & 36 & 16 & 17 & 0.02 & 061 & 002 & -0001 \\
\hline & & $2005 / 1 \cup 15$ & 19.5 & 7.44 & 2.000 & 105 & -19 & -2.6 & 1800 & 34 & 2500 & 10 & 6700 & 1000 & 18 & 12 & $a+1$ & $=0.1$ & 008 & 0.790 \\
\hline $\mathrm{P}-93$ & 436 & $2006: 0 \mathrm{~L} / \mathrm{18}$ & 18.7 & 7.46 & 1.961 & 7 & -19 & -2.8 & 1700 & 58 & 2800 & 190 & 6600 & 990 & 20 & 10 & 0.48 & -0.1 & 0.11 & 0.350 \\
\hline & & $2006 / 03 / 06$ & 18.5 & 7.45 & 1.846 & 149 & -17 & -2.5 & 1600 & 46 & 2400 & 170 & 6300 & 870 & 21 & 10 & 0.50 & $=0.1$ & 004 & 0.310 \\
\hline$P-111$ & 490 & $2006 / 03 / 06$ & 12.8 & 778 & 4.610 & 223 & 8 & -1.0 & 8500 & 70 & 1400 & 1200 & 18000 & 2300 & 65 & 25 & 2.50 & -0.1 & 000 & 4.300 \\
\hline & & $2005 / 1 \mathrm{~L} / 5$ & 19.5 & 731 & 1.696 & 215 & -11 & -1.4 & 2200 & 24 & 970 & 190 & 5100 & 920 & 38 & 11 & 093 & -0.1 & 002 & $0 .+10$ \\
\hline P.60 & $4 \times 8$ & $2006 / 03 / 06$ & 18.2 & 747 & 2.680 & 155 & -12 & -1.1 & 3800 & 58 & 1900 & 530 & 9300 & 1400 & 47 & 17 & L.40 & $=0.1$ & 000 & 0.900 \\
\hline$P-14$ & 47 & $2006 / 03 / 06$ & 17.3 & 7.38 & 2. 180 & 247 & -10 & -1.3 & 2800 & 39 & 1400 & 400 & 7500 & 970 & 37 & 6 & 1.40 & -0.1 & 000 & $0.00 \mathrm{I}$ \\
\hline & & $2006: 0 \mathrm{~L} / 19$ & 18.1 & 7.42 & 3.160 & 258 & 8 & 0.7 & 5300 & 160 & 1600 & 6.90 & 11000 & 1700 & 63 & 11 & 200 & $=0.1$ & 000 & 0.093 \\
\hline P.17 & 508 & $2006: 03 / 06$ & 18.0 & 745 & 3.560 & 228 & 8 & -1.1 & 5900 & 96 & 1600 & 790 & 1.3000 & 1900 & 68 & 17 & 2.20 & $=0.1$ & 000 & 0.200 \\
\hline
\end{tabular}

Table 1 (Continued) 


\begin{tabular}{|c|c|c|c|c|c|c|c|c|c|c|c|c|c|c|c|c|c|c|c|c|}
\hline Sumple Ne. & $\begin{array}{l}\text { Somple bedily } \\
\text { (TD m) }\end{array}$ & Dase & $\begin{array}{c}\text { Waliar } \\
\text { uemporidare } \\
\text { (c) }\end{array}$ & PH & $\begin{array}{l}\mathrm{FC} \\
\text { (Sim) }\end{array}$ & $\begin{array}{l}\text { ORP } \\
(\mathrm{mV})\end{array}$ & $3 \mathrm{D}$ & $3^{10} 0$ & $\mathrm{Na}$ & $\mathrm{K}$ & $\mathrm{ca}$ & Ste & C1 & $\mathrm{SO}_{4}$ & $\mathrm{HCO}$, & $\mathrm{SO}_{1}$ & $\mathrm{~B}$ & Al & $\mathrm{Fe}$ & Mh \\
\hline \multicolumn{21}{|c|}{ Nan 1 Popantewider wollary } \\
\hline \multirow{9}{*}{$\mathrm{P}-4$} & \multirow{9}{*}{20} & $2005 / 05 / 24$ & 20.0 & 700 & 0.320 & 231 & 43 & 6.5 & 28 & 2 & 31 & I & ş & 21 & 47 & 15 & 0.20 & $=0.1$ & & $=0001$ \\
\hline & & 2005.0614 & 20.1 & 805 & 0.040 & 1.37 & 42 & 6.3 & 32 & 2 & 32 & $\mathrm{t}$ & 36 & 20 & 41 & 15 & 0.24 & $=0.1$ & 001 & $0.00 \mathrm{t}$ \\
\hline & & 2005.0711 & 19.9 & 8.39 & 0.061 & 152 & -21 & -3.1 & 63 & 3 & 28 & 2 & 130 & 12 & 26 & 7 & 0.81 & $=0.1$ & 000 & 0.001 \\
\hline & & $2005 / 08 / 00$ & 22.4 & $8+4$ & 0.055 & 310 & .22 & -3.2 & 72 & 3 & 24 & 4 & 120 & 13 & 29 & 7 & 0.94 & & 000 & $=0001$ \\
\hline & & $2005 / 0 \times 12$ & 22.0 & 8.47 & 0.060 & 210 & -21 & -3.3 & 84 & 3 & 24 & 1 & 150 & 12 & 31 & 7 & Loo & & 001 & $=0001$ \\
\hline & & $2005 / 1013$ & 21.2 & 8.39 & 0.055 & 239 & -21 & -2.9 & 89 & 3 & 23 & t & 150 & 11 & 28 & 7 & Loo & & 001 & -00001 \\
\hline & & 2005/LL15 & 19.3 & 8.48 & 0.055 & 2.33 & .22 & -3.2 & 81 & 3 & 24 & 1 & 120 & 13 & 32 & 9 & as9 & & 000 & -0001 \\
\hline & & $2006.0 \mathrm{~L} / 19$ & 18.9 & 8.83 & 0.054 & 161 & .20 & -3.1 & $\pi$ & 4 & 25 & 1 & 120 & 13 & 30 & 7 & Q06 & & 000 & -0001 \\
\hline & & $2006 / 03 / 06$ & 19.5 & 762 & 0.047 & 318 & -12 & -1.8 & 77 & 5 & 14 & 2 & 120 & 7 & 25 & 3 & a.85 & $=0.1$ & 000 & 0.003 \\
\hline \multirow{2}{*}{ P.S } & \multirow{2}{*}{157} & $2005,04+18$ & 19.6 & 8.14 & 0.062 & 177 & -13 & -1.8 & 80 & 4 & 22 & I & 140 & 7 & 20 & 6 & L10 & $=0.1$ & 004 & $=0001$ \\
\hline & & $2005 / 05 / 24$ & 19.3 & 704 & 0.059 & 224 & -7 & -1.4 & 86 & 4 & 19 & 1 & 160 & 6 & 25 & 5 & L.20 & $=0.1$ & & -0001 \\
\hline \multirow{2}{*}{ P.7 } & \multirow{2}{*}{352} & $2005 / 0418$ & 19.2 & 786 & 0.044 & 192 & -31 & 4.4 & 52 & 2 & 28 & 1 & n & 11 & 31 & 11 & a.59 & $=0.1$ & 005 & $=0001$ \\
\hline & & $2005 / 05 / 24$ & 19.0 & 8.01 & 0.048 & 203 & .25 & -3.4 & 60 & 2 & 25 & t & 110 & 10 & 36 & 9 & a.79 & $=0.1$ & & - 0001 \\
\hline PA & 420 & $2006: 03 / 06$ & 18.9 & 701 & 0.432 & 261 & -12 & -1.8 & 460 & 7 & 330 & $s 2$ & 1300 & 140 & 26 & 5 & 0.78 & $=0.1$ & 001 & 0.008 \\
\hline Non.3 Proparewide & & & & & & & & & & & & & & & & & & & & \\
\hline P-105 & 93 & $20061 / 18^{*}$ & 18.7 & 789 & 0.028 & 234 & -52 & -8.1 & 22 & 3 & 36 & 1 & 30 & 30 & 60 & 17 & $=002$ & $=0.1$ & 001 & -0001 \\
\hline P.20 & 97 & $2005 / 0 \times 12$ & 21.6 & 756 & 0.027 & 241 & 49 & -7.9 & 19 & 2 & 28 & 2 & 20 & 29 & 63 & 14 & $-\infty 02$ & $=0.1$ & -0001 & $\infty 001$ \\
\hline & & $2005 / 05 / 24$ & 19.4 & 8.19 & 0.048 & 203 & .25 & -3.6 & 64 & 3 & 24 & t & 110 & 11 & 46 & 9 & 080 & $=0.1$ & & - 001 \\
\hline & & 2005.0614 & 20.1 & 8.16 & 0.049 & 198 & .29 & -3.9 & 67 & 3 & 24 & 1 & 100 & 11 & 36 & 10 & 0.76 & 0.16 & 0.22 & 0.003 \\
\hline & & $2005.07 \mathrm{II}$ & 20.4 & 8.24 & 0.042 & 228 & -32 & 4.9 & 53 & 3 & 21 & I & 89 & 14 & 40 & 10 & 0.56 & $=0.1$ & 001 & - 0001 \\
\hline & & $2005 / 0800$ & 20.6 & 8.12 & 0.053 & 252 & .29 & 4.4 & 62 & 3 & 30 & 3 & 120 & 16 & 35 & 10 & ant & 0.13 & 001 & 0.002 \\
\hline P-19 & 134 & $2005 / 0 \times 12$ & 20.6 & 805 & 0.045 & 2.32 & -3.3 & 4.9 & 61 & 3 & 22 & I & 96 & 15 & 39 & 9 & 0.63 & $=0.1$ & $=0001$ & $=0001$ \\
\hline & & $2005 / 10$ เ3 & 20.4 & 8.16 & 0.052 & 257 & .29 & 4.3 & $\pi$ & 3 & 32 & 2 & 120 & 14 & 42 & 10 & 0.74 & -0.1 & 000 & $=0001$ \\
\hline & & $2005 / 1 \mathrm{~L} / 5$ & 19.5 & 8.05 & 0.048 & 252 & 30 & 4.5 & 65 & 3 & 26 & t & 100 & 15 & 42 & 11 & 0.66 & & 001 & -0001 \\
\hline & & $20061 / 18^{*}$ & 18.8 & 8.19 & 0.045 & 198 & 30 & 4.7 & 59 & 3 & 29 & 1 & 85 & 16 & 43 & 11 & 0.55 & $=0.1$ & $=0001$ & -0001 \\
\hline & & $2006: 03 / 06$ & 18.5 & 8.24 & 0.041 & 359 & .26 & 4.1 & 54 & 3 & 24 & I & $x$ & 14 & 40 & 9 & 0.52 & $=0.1$ & 000 & $=0001$ \\
\hline P.74 & 2.39 & $2006 / 0 \% 12$ & 22.8 & 8.46 & 0.000 & 222 & 4 & 0.7 & 150 & 7 & 13 & 2 & 240 & 5 & 30 & 2 & L60 & 0.1 & $=0001$ & $=0001$ \\
\hline P.75 & 245 & $2006 / 0 \times 12$ & 23.6 & 724 & 0.086 & 249 & -5 & 0.8 & 140 & 7 & 7 & 2 & 240 & 5 & 20 & t & L60 & $=0.1$ & $=0001$ & 0.002 \\
\hline P-104 & 248 & $2006: 0 \mathrm{~L} / 8$ & 17.3 & 7.30 & 0.062 & 132 & 4 & 0.6 & 110 & 6 & 4 & 2 & 170 & 5 & 18 & 1 & L.30 & $=0.1$ & 020 & 0.001 \\
\hline$P, 32$ & 45 & $2006.0 \mathrm{~L} / \mathrm{l}$ & 18.2 & 764 & 0.568 & 260 & 49 & -7.4 & 540 & 9 & 64) & 34 & 1700 & 240 & 66 & 16 & 0.42 & $=0.1$ & -0001 & 0.130 \\
\hline$p=32$ & 45 & $2006 / 03 / 06$ & 18.7 & 795 & 0.193 & 342 & .21 & -3.1 & 170 & 4 & 80 & 5 & 360 & 45 & 40 & 8 & 0.74 & $=0.1$ & 001 & 0.002 \\
\hline P-110 & 492 & $2006 / 03 / 06$ & 17.7 & 786 & 0.450 & 257 & 46 & 6.9 & 650 & 9 & 20 & 33 & 1300 & 180 & $9 \mathrm{I}$ & 15 & 0.58 & $=0.1$ & 000 & 0.099 \\
\hline P-109 & 508 & $2006 / 03 / 06$ & 18.8 & 767 & 4.200 & 229 & -1.3 & -1.9 & 7900 & 94 & 1300 & 960 & 15000 & 2100 & 130 & 13 & 250 & $=0.1$ & 001 & 19 \\
\hline Fenench bumal (Pwep & & & & & & & & & & & & & & & & & & & & \\
\hline P-15 & - & 2005,0418 & 19.3 & 7.37 & 2.700 & 74 & -35 & -5.1 & 1800 & 18 & 2800 & 500 & 8800 & 890 & 80 & 16 & 0.26 & $=0.1$ & 003 & 56 \\
\hline$P 69$ & 245 & $2006,0 \mathrm{~L} / 9$ & 18.3 & 748 & 1.224 & 173 & 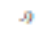 & -1.2 & 1800 & 23 & 890 & 8 & 3700 & 890 & 14 & I & 0.88 & -00.1 & 0.49 & 0.40 \\
\hline & & $2005,05 / 24$ & 21.3 & 695 & 2.210 & 16 & -36 & 5.0 & 1900 & 18 & 2400 & 40 & 7800 & 850 & 92 & 16 & 0.30 & $=0.1$ & & 52 \\
\hline & & 2005.0711 & 20.3 & 723 & 2.200 & 158 & -34 & 5.0 & 2000 & 18 & 2200 & 450 & 8200 & 920 & 81 & 15 & 0.31 & $=0.1$ & 002 & 5.5 \\
\hline & & $2005 / 0800$ & 21.0 & 724 & 2.30 & 226 & -33 & -5.0 & 2100 & 20 & 2400 & 510 & 8400 & 970 & 86 & 15 & 0.36 & & 000 & 64 \\
\hline P-16 & 917 & $2005 / 1013$ & 20.5 & 727 & 2.400 & 220 & -32 & 4.7 & 2500 & 13 & 2500 & 560 & 8800 & 1000 & 88 & 16 & 0.40 & & 006 & 58 \\
\hline & & $2005 / 1 \mathrm{~L} / 15$ & 19.9 & 727 & 2.520 & 208 & -32 & 4.6 & 2600 & 14 & 2500 & 540 & 8400 & 1000 & 89 & 16 & 0.32 & & 007 & 78 \\
\hline & & $2006: 0 \mathrm{~L} / 19$ & 19.0 & 7.37 & 2.650 & 132 & -31 & 4.5 & 2800 & 50 & 2700 & 50 & 9500 & 1100 & 91 & 17 & 0.45 & & $=0001$ & 72 \\
\hline & & $2006 / 0306$ & 19.1 & 706 & 2.730 & 138 & -31 & 4.5 & 2900 & 38 & 3600 & 600 & 9700 & 1200 & 92 & 20 & 0.52 & $=0.1$ & 000 & 8.5 \\
\hline P.50 & 19 & $2006 / 0 \mathrm{~L} / \mathrm{l}$ & 18.5 & 763 & 0.359 & 179 & 4 & 0.5 & 520 & 10 & $1 w$ & 54 & 1000 & 110 & 22 & 2 & L.30 & $=0.1$ & $00 \mathrm{t}$ & 0.003 \\
\hline P.S9 & 11 & $2006 / 0 \mathrm{~V} / 8$ & 18.5 & 739 & $4 \infty 0$ & 215 & -7 & .0 .5 & 8700 & 160 & 1500 & 100 & 17000 & 2500 & 90 & 11 & 280 & $=0.1$ & -0001 & 0.015 \\
\hline & & $2005 / 1 \mathrm{~L} / \mathrm{s}$ & 20.0 & 7.52 & 3.40 & 114 & .21 & -2.9 & 5800 & 45 & 720 & 660 & 11000 & 970 & 100 & 15 & 1.80 & $=0.1$ & 003 & 15 \\
\hline$P \cdot 2 / 2$ & 19 & $2006.0 \mathrm{~L} / \mathrm{l}$ & 17.1 & 761 & 3.370 & 171 & -20 & 3.1 & 5900 & 69 & 1600 & 700 & 12000 & 2000 & 100 & 21 & 210 & $=0.1$ & $=0001$ & 14 \\
\hline & & $2006 / 03 / 06$ & 18.0 & 7.40 & 3.150 & 130 & -14 & -2.2 & 5500 & 57 & 1200 & 690 & 11000 & 1800 & 87 & 13 & 200 & $=0.1$ & 001 & 12 \\
\hline & & $2005 / 0418$ & 19.1 & 747 & 1.218 & 40 & 46 & -6.6 & 1400 & 15 & 990 & 140 & 3900 & 510 & 49 & 16 & 0.39 & $=0.1$ & 0.04 & 0.590 \\
\hline & & 2006/10 13 & 19.7 & 7.18 & 2.260 & 126 & -36 & 5.3 & 3100 & 26 & 1500 & 390 & 7200 & 1100 & 72 & 15 & 0.94 & $=0.1$ & 0.31 & 12 \\
\hline P.3.3 & 60 & $2005 / 1 \mathrm{~V} / 5$ & 18.9 & 724 & 2.390 & 109 & -36 & -5.0 & 3200 & 28 & 1500 & 300 & 7500 & 1100 & 75 & 15 & 0.76 & & 000 & 1.3 \\
\hline & & $2006 / 01 / 18$ & 17.9 & 7.13 & 2.280 & 83 & -34 & 5.0 & 3500 & 60 & 1700 & 430 & 8300 & 1100 & 81 & 17 & a99 & & 0.77 & 1.3 \\
\hline & & $2006 / 03 / 06$ & 18.7 & 7.18 & 2.410 & 113 & -34 & 5.1 & 3400 & 40 & 1700 & 390 & 810 & 1100 & $\pi$ & 15 & Loo & $=0.1$ & 000 & 1.3 \\
\hline Nen 2 Pripoure cine & & & & & & & & & & & & & & & & & & & & \\
\hline$P-62$ & 180 & $2005 / 06 / 4$ & 22.5 & 9.70 & 0.072 & 94 & -7 & 0.9 & 110 & 5 & 19 & 1 & 170 & 9 & 18 & 9 & L.30 & a.so & 003 & $=0001$ \\
\hline P.5.3 & 208 & 2005.0614 & 20.4 & 907 & 0.068 & 120 & -5 & 0.8 & 110 & 5 & 12 & 2 & 170 & 4 & 18 & 2 & L.40 & 0.12 & 0.10 & -001 \\
\hline P-81 & 421 & 2006:03/07 & 17.4 & 799 & 0.246 & 278 & $A$ & -1.4 & 360 & 5 & 92 & 12 & 700 & 86 & 2.3 & 9 & a.75 & $=0.1$ & 003 & 0.004 \\
\hline P-114 & 483 & $2006: 03 / 07$ & 19.3 & 1068 & 1.870 & 87 & 53 & -7.7 & 1000 & 11 & 3100 & 3 & 6600 & 410 & 11 & 13 & 004 & $=0.1$ & 000 & 0.001 \\
\hline P-115 & 485 & $2006 / 03 / 07$ & 19.6 & 8.90 & 0.47 & 125 & $\rightarrow$ & -1.4 & 630 & 6 & (4) & 46 & 1200 & 180 & 24 & 3 & $a n_{2}$ & $=0.1$ & 000 & 0.003 \\
\hline Nen I Pripuare conic & & & & & & & & & & & & & & & & & & & & \\
\hline$P 95$ & 425 & $2005 / 1 \mathrm{~L} / 5$ & 20.0 & 7.58 & 0.596 & 228 & .26 & 40 & 580 & 7 & 430 & 43 & 1600 & 200 & 30 & 12 & 0.64 & $=0.1$ & 002 & 0.060 \\
\hline
\end{tabular}

Table 1 (Continued) 


\begin{tabular}{|c|c|c|c|c|c|c|c|c|c|c|c|c|c|c|c|c|c|c|c|c|}
\hline Somple Ner & $\begin{array}{l}\text { Semple beally } \\
\text { (ID m) }\end{array}$ & Dase & $\begin{array}{c}\text { Widar } \\
\text { lemporibure } \\
\text { (C) }\end{array}$ & $\mathrm{pH}^{\mathrm{H}}$ & $\begin{array}{l}\text { FC. } \\
\text { (Sm) }\end{array}$ & $\begin{array}{l}\mathrm{ORP} \\
(\mathrm{mV})\end{array}$ & (E) & $b^{110} 0$ & $\begin{array}{c}\mathrm{Na} \\
(m \mathrm{~m} 1 .)\end{array}$ & $\mathrm{K}$ & 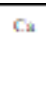 & Me & $\mathrm{C} 1$ & $\mathrm{SO}_{4}$ & $\mathrm{HCO}$, & $\mathrm{SWO}_{2}$ & $\mathrm{~B}$ & Al & Fe & $\mathrm{Mh}$ \\
\hline \multicolumn{21}{|l|}{ Worlaing tovend } \\
\hline $\mathrm{T}-\mathrm{L}$ & 250 & $2006 / 0 \mathrm{~L} / 19$ & 16.0 & 755 & 1.404 & 246 & -35 & .5 .5 & 2500 & 97 & (4) & 320 & 4500 & 670 & 110 & 31 & a.93 & $=0.1$ & 001 & 0.003 \\
\hline TA & si & $2006: 01 / 9$ & 16.7 & 7.14 & 4.290 & 251 & 5 & 0.4 & 10000 & tho & 530 & 1300 & 18000 & 2600 & 98 & 14 & 380 & $=0.1$ & $=0001$ & 0.73 \\
\hline \multirow{2}{*}{$\mathrm{T} / \mathrm{s}$} & \multirow{2}{*}{710} & $2005 / 0615$ & 19.7 & 780 & 0.462 & 143 & 47 & -7.1 & 290 & 4 & $s t 0$ & 98 & 1400 & 140 & 83 & 20 & $=02$ & $=0.1$ & 004 & 0.002 \\
\hline & & $2006.0 \mathrm{~V} / 9$ & 16.2 & 750 & 0.406 & 260 & 46 & -7.0 & 260 & 6 & $5 \$ 0$ & 130 & 1500 & 170 & 95 & 21 & 0.03 & $=0.1$ & 000 & 0.012 \\
\hline $\mathrm{T} 4$ & 717 & $2005 / 0418$ & 17.8 & 785 & 0.435 & 242 & 49 & -7.4 & 320 & 4 & 460 & $n$ & 1400 & 120 & 75 & 20 & $=0.1$ & $=0.1$ & 006 & $=001$ \\
\hline \multirow{7}{*}{ T-7 } & \multirow{7}{*}{20} & $2005 / 0418$ & 18.2 & 748 & 4.810 & 252 & -7 & -0.4 & 9700 & 350 & 390 & 100 & 18000 & 2500 & 76 & 15 & 3.80 & $=0.1$ & 002 & 1.4 \\
\hline & & $2005 / 05 / 24$ & 19.5 & 7.52 & 4.830 & 130 & 6 & .0 .3 & 9900 & 40 & 400 & 1200 & 18000 & 2500 & 90 & 15 & 3.40 & -0.1 & & 1.3 \\
\hline & & $2005 / 0712$ & 21.1 & 7.18 & 4.840 & 130 & -6 & -0.3 & 9500 & 370 & 430 & 1 too & 18000 & 2500 & 69 & 17 & 300 & $=0.1$ & 002 & 09 \\
\hline & & $2005 / 08$ to & 21.9 & 751 & 4.850 & 230 & -7 & .0 .5 & 9700 & 400 & 430 & 1200 & 18000 & 2600 & 72 & 13 & 3.50 & & 005 & 0.5 \\
\hline & & $2005 / 1 \mathrm{~L} / 5$ & 19.1 & 7.58 & 4.20 & 240 & 6 & 0.4 & 10000 & 360 & 410 & 1200 & 18000 & 2500 & 86 & 15 & 3.50 & & 002 & 02 \\
\hline & & $2006.0 \mathrm{~L} / 19$ & 15.9 & 7.51 & 5.0t0 & 261 & 4 & -0.4 & 10000 & $\$ 20$ & 44) & 1200 & 18000 & 2600 & 85 & 15 & 400 & & 001 & 0.005 \\
\hline & & $2006.03 / 07$ & 20.8 & 764 & 5.020 & 318 & -5 & -0.2 & 10000 & tho & 410 & 1300 & 19000 & 2600 & 80 & 19 & 410 & $=0.1$ & 000 & 0.030 \\
\hline Oltemation vell & Depulh (Flcicalivn; mAS1.) & & & & & & & & & & & & & & & & & & & \\
\hline \multirow{2}{*}{ Ne.1 } & & $2005 / 05 / 25$ & 19.5 & 8.04 & 0.097 & 107 & 49 & -7.5 & 28 & $t$ & 39 & 2 & $3 t$ & 26 & 109 & 44 & -002 & -0.1 & 001 & $-000 t$ \\
\hline & -27.27 & $2005 / 1 / 1 / 4$ & 16.8 & 744 & 0.044 & 96 & so & -7.6 & 28 & 3 & 46 & 5 & 2 & 25 & 94 & 82 & $=002$ & -0.1 & 001 & -0001 \\
\hline W. 5 & 1368 & $2005 / 0615$ & 19.0 & 7.78 & 0.020 & 57 & -54 & -8.0 & 12 & 3 & 24 & 1 & 16 & 14 & 53 & 23 & -002 & $=0.1$ & 0.18 & 0.052 \\
\hline Nos & -13.68 & $2005 / 1 \mathrm{~L} 15$ & 16.3 & 8.05 & 0.024 & 82 & -54 & -8.0 & 12 & 3 & 34 & 2 & 18 & 11 & $\pi$ & 24 & $=002$ & $=0.1$ & 004 & 0.075 \\
\hline & & $2005 / 05 / 25$ & 18.2 & 7.47 & 0.091 & 1 & si & -7.6 & 27 & 2 & 21 & 4 & 27 & 24 & 92 & 30 & $=002$ & $=0.1$ & 004 & 0.090 \\
\hline Nas $7-1$ & -10.3 & $2005 / 05 / 25$ & 18.9 & 741 & 0.091 & 64 & -50 & -7.7 & 28 & 2 & 19 & 4 & 28 & 26 & 86 & 30 & $=002$ & $=0.1$ & 004 & 0.004 \\
\hline & & $2005 / 1 \mathrm{~L} / 5$ & 15.8 & 7.51 & 0.028 & 134 & -51 & -7.7 & 29 & 2 & 20 & 5 & 36 & 28 & 56 & 59 & -002 & $=0.1$ & 008 & -0001 \\
\hline & & $2005 / 05 / 25$ & 18.1 & 795 & 0.092 & 47 & -51 & -7.9 & 18 & 4 & 39 & 1 & 21 & 16 & 133 & 29 & $=002$ & $=0.1$ & 004 & 0.002 \\
\hline Nege & 268.5 & $2005 / 1 \mathrm{~V} / \mathrm{s}$ & 16.3 & 754 & 0.093 & 1 & -52 & 8.0 & 19 & 4 & 48 & 2 & 30 & 16 & 110 & 32 & $=002$ & $=0.1$ & 000 & 0.005 \\
\hline $\mathrm{N}=10 \mathrm{~d}$ & 2449 & $2006 / 05 / 25$ & 18.9 & 903 & 0.099 & 100 & so & -7.6 & 35 & 4 & 28 & $\mathrm{t}$ & 45 & 45 & 64 & 25 & $=002$ & $=0.1$ & 001 & - 0001 \\
\hline $\sec =10-1$ & $24+4)$ & $2005 / 1 \mathrm{~V} / 5$ & 16.2 & 8.80 & 0.034 & -82 & so & -7.7 & 34 & 3 & 28 & 2 & 32 & 41 & 61 & 26 & -002 & -0.1 & 001 & $=0001$ \\
\hline $\operatorname{Nan} 10-2$ & -19.41 & $2005 / 1 / 15$ & 16.5 & 920 & 0.094 & -131 & -50 & -7.7 & 34 & 3 & 33 & 2 & 33 & 41 & 58 & 29 & -002 & $=0.1$ & 001 & -0001 \\
\hline & & $2005 / 05 / 25$ & 17.5 & 762 & 0.058 & 134 & 48 & .7 .5 & 44 & 6 & 56 & 7 & 81 & 44 & 144 & 26 & $=002$ & $=0.1$ & 005 & 0.002 \\
\hline Nenll & 1151 & $2005 / 1$ V 15 & 15.9 & 803 & 0.047 & 107 & so & -7.6 & 44 & 8 & 46 & 6 & ss & 42 & 90 & 36 & -002 & $=0.1$ & 000 & 0.002 \\
\hline & & $2005 / 0615$ & 18.8 & 754 & 0.093 & 257 & -31 & -7.8 & 21 & 2 & 25 & 4 & 17 & 33 & 73 & 25 & $-\infty 02$ & $=0.1$ & 000 & 0.004 \\
\hline $\mathrm{N}=12$ & -40.18 & $2005 / 1$ L & 16.4 & 794 & 0.027 & 147 & -31 & -7.8 & 22 & 2 & 25 & 5 & 16 & 31 & 67 & 26 & $-\infty 02$ & -0.1 & 000 & -0001 \\
\hline & & $2005 / 05 / 25$ & 23.6 & 680 & 0.046 & & so & -7.5 & 46 & 0 & 23 & 6 & 4) & 49 & 90 & 43 & $=002$ & $=0.1$ & 001 & -0001 \\
\hline & & $2005 / 08$ to & 26.1 & 665 & 0.041 & 290 & 49 & -7.5 & 43 & 1 & 24 & 7 & 61 & 46 & 76 & 40 & 001 & & 001 & $=0001$ \\
\hline $\mathrm{Nan} 15$ & Privide well & $2005 / 0 \times 13$ & 21.9 & 6.11 & 0.041 & & so & -7.5 & 41 & 0 & 27 & 9 & 48 & 55 & 69 & 36 & -002 & $=0.1$ & -0001 & -0001 \\
\hline & & $2005 / 1$ L L & 18.4 & 6.56 & 0.041 & 2.33 & 49 & -7.6 & 46 & 0 & 24 & 6 & 46 & 42 & 60 & 42 & $=002$ & $=0.1$ & 0.11 & 0.009 \\
\hline & & $2006: 01 / 19$ & 15.7 & 6.82 & 0.042 & 251 & -51 & -7.7 & 47 & 0 & 29 & 6 & 4) & 46 & 89 & 42 & -002 & & 002 & -0001 \\
\hline & & $2005 / 06 / 5$ & 19.4 & 7,43 & 0.008 & 197 & 49 & -7.6 & 24 & 2 & 24 & 5 & 24 & 26 & 58 & 24 & -002 & $=0.1$ & 0.04 & $0.0 \mathrm{t}$ \\
\hline $\operatorname{Na}=17$ & -23.77 & $2005 / 1 / 15$ & 15.8 & 780 & 0.029 & 91 & 47 & -7.6 & 25 & 3 & 24 & 5 & 21 & 29 & 62 & 28 & -002 & $=0.1$ & 000 & - Doot \\
\hline & & $2005 / 06$ 15 & 19.0 & 780 & 0.026 & 179 & 49 & -7.6 & 19 & 2 & 24 & 4 & 18 & 25 & 52 & 22 & $=002$ & -0.1 & 0.12 & 0.004 \\
\hline$N=25-1$ & $-6129--10029$ & $2005 / 1 / 14^{*}$ & 16.3 & 8.07 & 0.097 & 87 & so & -7.6 & 20 & 2 & 27 & 4 & 18 & 27 & 47 & 26 & -002 & $=0.1$ & 003 & $-000 \mathrm{I}$ \\
\hline Ne. 25-2 & $-106.79--139.79$ & $2005 / 1 / 14^{7}$ & 16.3 & 820 & 0.029 & -140 & -31 & -7.9 & 20 & 2 & 2.3 & 2 & 21 & 16 & 46 & 21 & $=02$ & Q.13 & 0.30 & 0.002 \\
\hline Ne. 25-3 & $-141.29-17029$ & $2005 / 11 / 4$ & 16.4 & 8.21 & 0.020 & -177 & 52 & -7.9 & 25 & 2 & 13 & 1 & 22 & 12 & 38 & 19 & -002 & -0.1 & 004 & 0.061 \\
\hline $\sin 29$ & -25.62 & $2006 / 05 / 25$ & 17.2 & 6.14 & 0.030 & 58 & -52 & -7.9 & 21 & I & 22 & 5 & $\boldsymbol{2}$ & 24 & 66 & 30 & -002 & $=0.1$ & 0.03 & 0.040 \\
\hline $\operatorname{Ne} 29$ & -25.62 & $2005 / 1$ V 15 & 16.3 & 600 & 0.009 & 45 & -55 & -8.4 & 20 & 6 & 18 & 5 & 28 & 22 & 63 & 39 & $=002$ & $=0.1$ & 001 & 0.72 \\
\hline $\mathrm{Ne}=39$ & -41.18 & $200555 / 25^{\circ}$ & 16.9 & 11.55 & 0.103 & 53 & -30 & 4.4 & 60 & 7 & 69 & 0 & $\theta$ & 16 & 2 & 12 & 049 & 0.70 & 001 & -0001 \\
\hline $\mathrm{N}=40-2$ & -1.27 & $2005 / 1$ V 15 & 15.8 & 8.34 & 0.090 & 21 & 49 & -7.5 & 21 & 2 & 36 & 5 & 18 & 36 & 76 & 69 & $=002$ & $=0.1$ & 000 & $0.00 \mathrm{t}$ \\
\hline $\mathrm{Na}=40-3$ & $90-85$ & $2005 / 05 / 23$ & 17.0 & 755 & 0.031 & 230 & 49 & -7.4 & 20 & 3 & 28 & 5 & 30 & 40 & 52 & 26 & $=002$ & 0.21 & 0.74 & 0.014 \\
\hline $\mathrm{Ne}-40-4$ & -51.97 & $2005 / 1 \mathrm{~L} / \mathrm{L}$ & 16.1 & 8.31 & 0.028 & -114 & -51 & -7.7 & 20 & 2 & 30 & 3 & 19 & 30 & 63 & 21 & -002 & $=0.1$ & 000 & -0001 \\
\hline$N=40-6$ & -111.97 & $2005 / 1 \mathrm{~L} / 5$ & 15.7 & 8.44 & 0.027 & -55 & -51 & -7.9 & 21 & $\mathrm{t}$ & 27 & I & 17 & 23 & 57 & 18 & $=002$ & $=0.1$ & 009 & 0.005 \\
\hline Othex (Ond d muenen) & & & & & & & & & & & & & & & & & & & & \\
\hline & & 2005,0418 & 15.0 & 8.43 & 0.046 & 174 & .22 & .3 .2 & 75 & 4 & 6 & 3 & 120 & 7 & 14 & 6.9 & 0.88 & $=0.1$ & 006 & -0001 \\
\hline & & $2005 / 05 / 24$ & 19.6 & 784 & 0.072 & 120 & 4 & -0.6 & 110 & 5 & I & 2 & 170 & 4 & 8 & 0.2 & 1.40 & $=0.1$ & & -0001 \\
\hline & & $2005 / 0615$ & 22.4 & 744 & 0.062 & 93 & $g$ & -1.5 & 100 & 5 & 3 & 2 & 160 & 5 & 11 & 2.1 & L.30 & $=0.1$ & 001 & - 0001 \\
\hline & & $2005 / 0712$ & 24.5 & 8.32 & 0.064 & 173 & $-s$ & 0.5 & 98 & 5 & 3 & 4 & 150 & 4 & 7 & 0.4 & L.30 & $\infty 0.1$ & 003 & -0001 \\
\hline & & $2005 / 0810$ & 27.0 & 769 & 0.078 & 238 & -7 & -1.0 & 110 & 5 & 2 & $s$ & 180 & 5 & 12 & 2.0 & $L 40$ & & $00 \mathrm{~L}$ & -00001 \\
\hline Scoll widist & & $2005: 0 \times 13$ & 27.6 & 7.35 & 0.077 & ND & 4 & 0.5 & 130 & 6 & I & 2 & 220 & 4 & 8 & 0.1 & L70 & -0.1 & 000 & -0001 \\
\hline & & $2005 / 1 \mathrm{~L} / \mathrm{S}$ & 21.6 & 700 & 0.067 & 263 & 4 & 0.6 & 120 & 5 & $\mathrm{t}$ & 2 & 160 & 5 & 7 & 4.6 & L.10 & $=0.1$ & 001 & -0001 \\
\hline & & $2006: 04 / 19$ & 12.5 & 6.46 & 0.064 & 379 & -5 & .0 .4 & 120 & 6 & 1 & 2 & 180 & 4 & 14 & 0.4 & L.30 & $=0.1$ & $00 \mathrm{t}$ & -0001 \\
\hline & & $2006: 03 / 07$ & 16.1 & 696 & 0.098 & 513 & -7 & -1.4 & 67 & 4 & 1 & 2 & 110 & 4 & 7 & 1.0 & 067 & -0.1 & 001 & -0001 \\
\hline & & $2005 / 1014$ & 26.1 & 705 & 0.073 & 288 & -5 & 0.7 & 130 & 5 & 3 & 4 & 210 & 3 & 6 & 0.1 & L60 & & 001 & -0001 \\
\hline & & $2006 / 0 \mathrm{~L} / 9$ & 8.0 & ותו & 0.008 & 344 & -13 & -1.8 & 12 & 1 & $t$ & 0 & 19 & 1 & 9 & 0.0 & 0.23 & $=0.1$ & ODI & -0001 \\
\hline New yod wider & & $2006: 0207$ & 19.7 & 790 & 0.013 & 410 & -13 & .2 .0 & 20 & 1 & 2 & I & 30 & 2 & 9 & 0.1 & 0.12 & $=0.1$ & $00 \mathrm{t}$ & 0.002 \\
\hline & & $2006: 03 / 07$ & 19.0 & 708 & 0.006 & 488 & -11 & -1.9 & 9 & 0 & 0 & 0 & 14 & 1 & 10 & 0.2 & a.s & $=0.1$ & 000 & -0001 \\
\hline Soi willer & & 2005 ins 10 & 25.2 & 797 & 4.50 & 242 & 4 & 0.3 & 10000 & 430 & 390 & 1200 & 18000 & 2600 & 9 & 0.5 & 4.40 & $=0.1$ & 001 & -0001 \\
\hline Procipiblix & & $2006,03 / 06$ & 9.4 & 662 & 0.004 & 520 & .20 & -5.4 & 1 & 0 & 2 & 0 & 3 & 7 & 9 & 0.8 & $=002$ & $=0.1$ & 001 & 0.008 \\
\hline
\end{tabular}

Table $2 \delta^{18} \mathrm{O}$ and $\mathrm{Cl}$ concentration values for the three end-members.

\begin{tabular}{cccc}
\hline End member & $\delta \mathrm{D}$ & $\delta^{18} \mathrm{O}$ & $\mathrm{Cl}$ \\
& $\%$ & $\%$ & $\mathrm{mg} / \mathrm{L}$ \\
\hline Sea water & -6.4 & -0.5 & 18,300 \\
Seal water & -7.1 & -0.6 & 110 \\
Groundwater & -49.8 & -8.0 & 15 \\
\hline
\end{tabular}


Figures

(a)

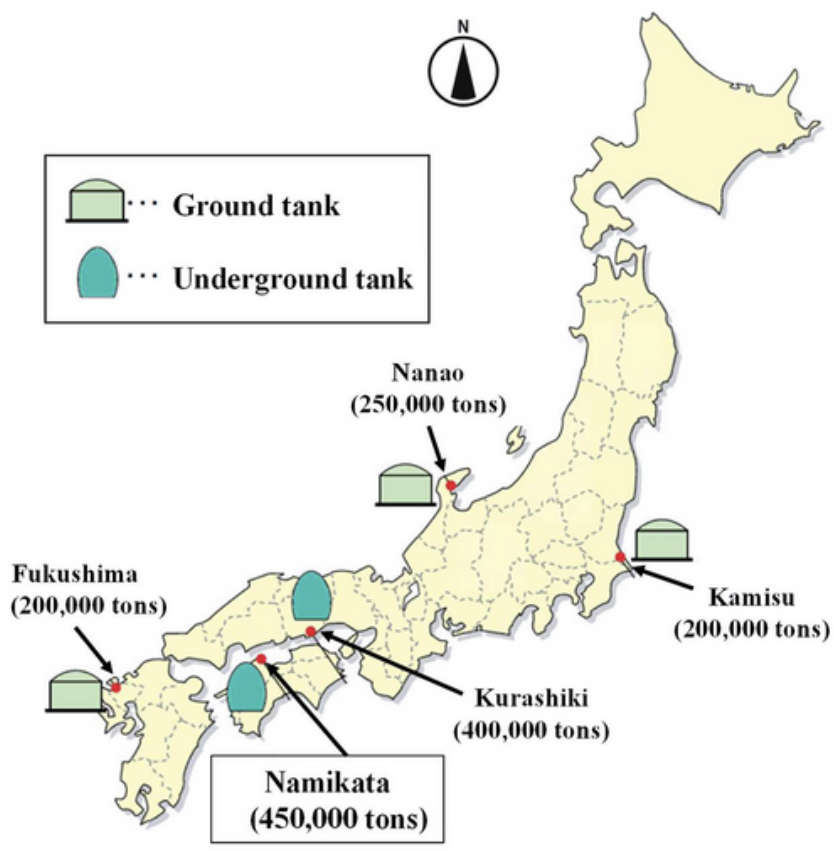

(b)

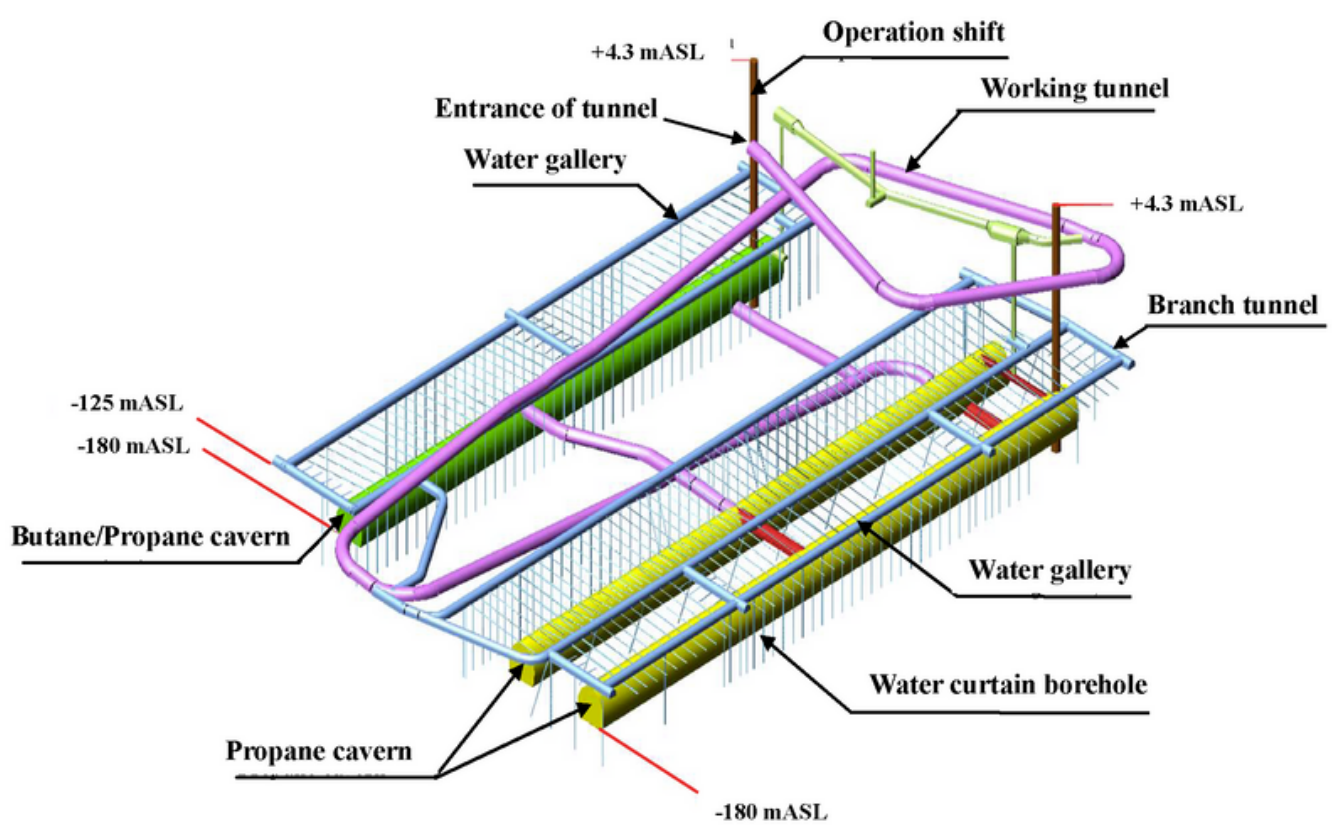

Figure 1

(a) Location and (b) tunnels of the underground storage base for LPG. (Modified from the location of LPG stockpiles in Japan; Ministry of Economy, Trade and Industry, https://www.meti.go.jp/press/2017/ 11/20171102002/20171102002.html.) 


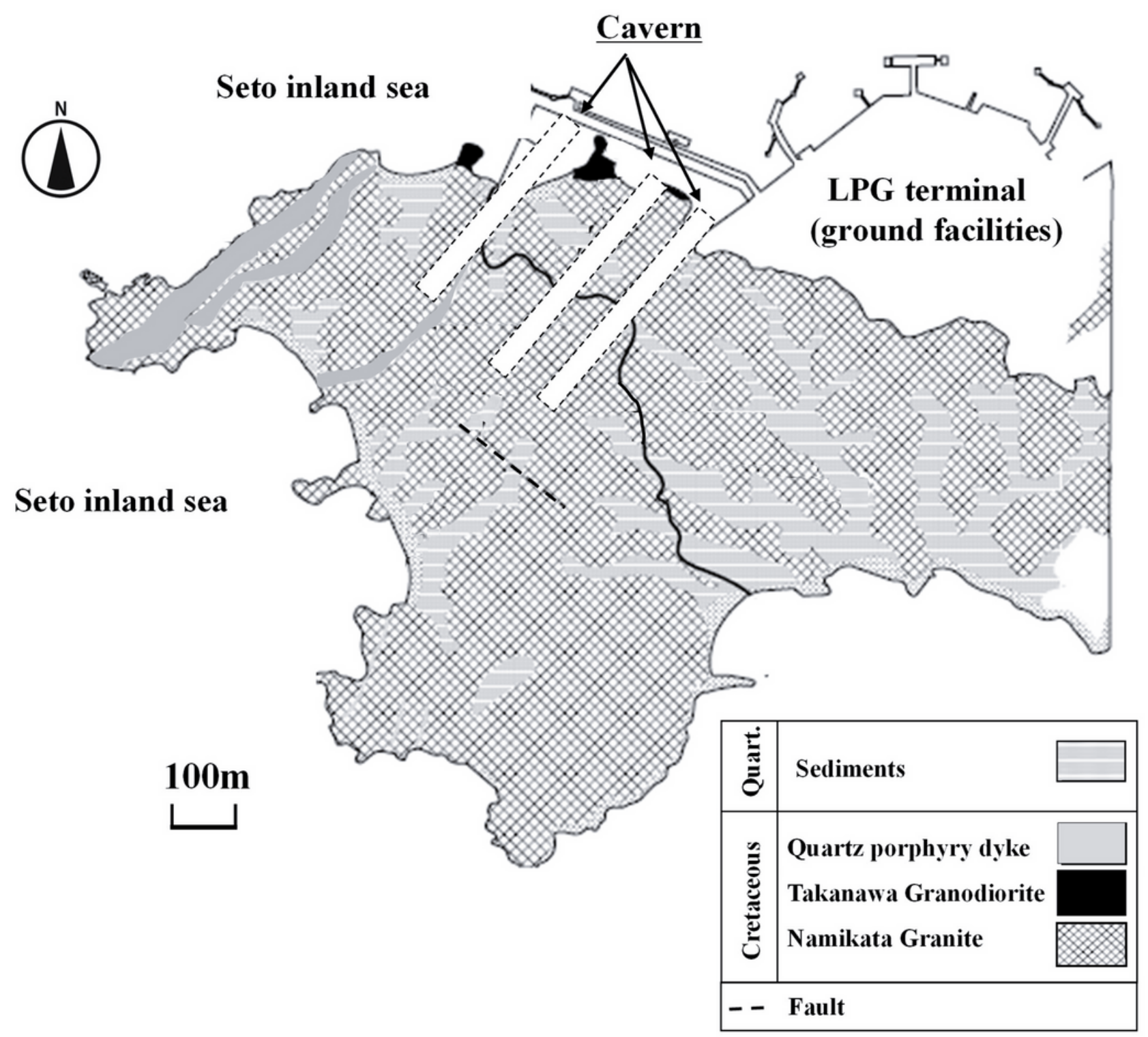

Figure 2

Geological map of the study area. (Modified from Otake, 2000.) 


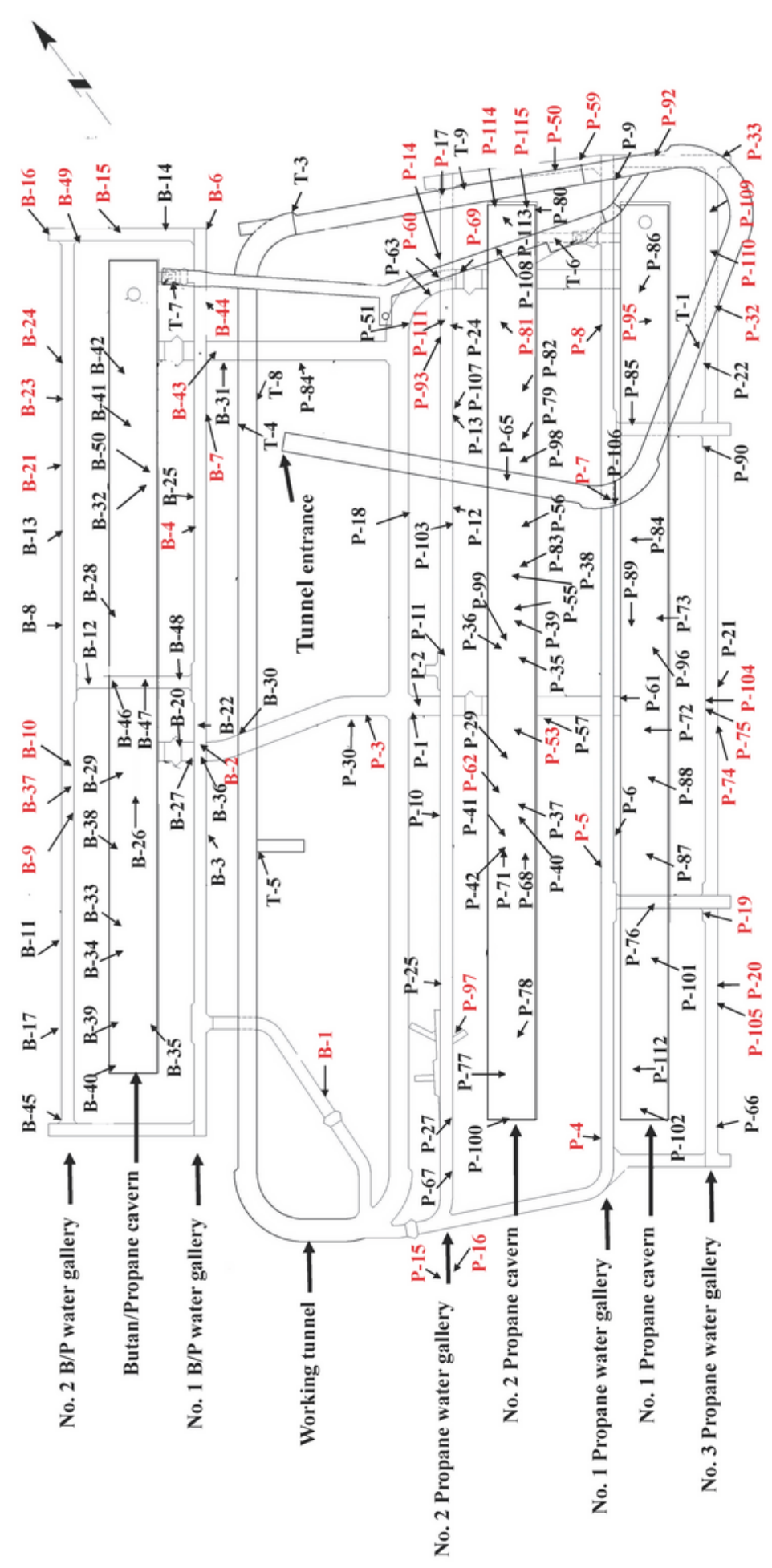

Figure 3

$\delta D$ vs. $\delta 180$ of water samples in the study area. $\bullet$ : Propane area, $\bullet$ : Butane/Propane area, $\mathbf{\bullet}$ : working tunnel, $\mathbf{\square}$ : observation well, $\triangle$ : seal water, $\square$ : seawater. 


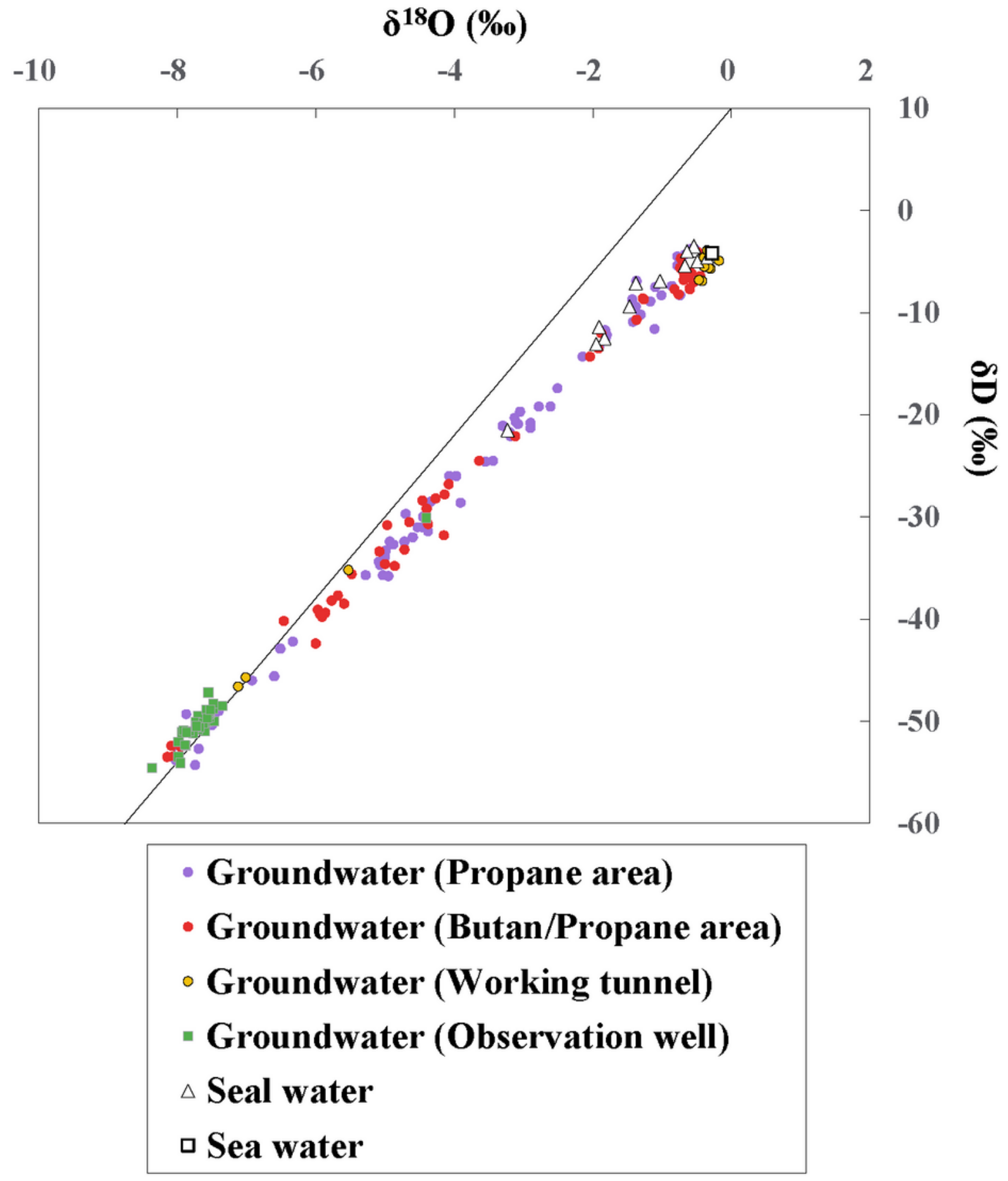

Figure 4

(a) $\delta 180$ vs. Cl. (b) change of the percentage of the three end-members at the water sampling site (March 2005 to February 2006). End-member diagrams for (c) working tunnel, (d) water gallery, and (e) cavern. 

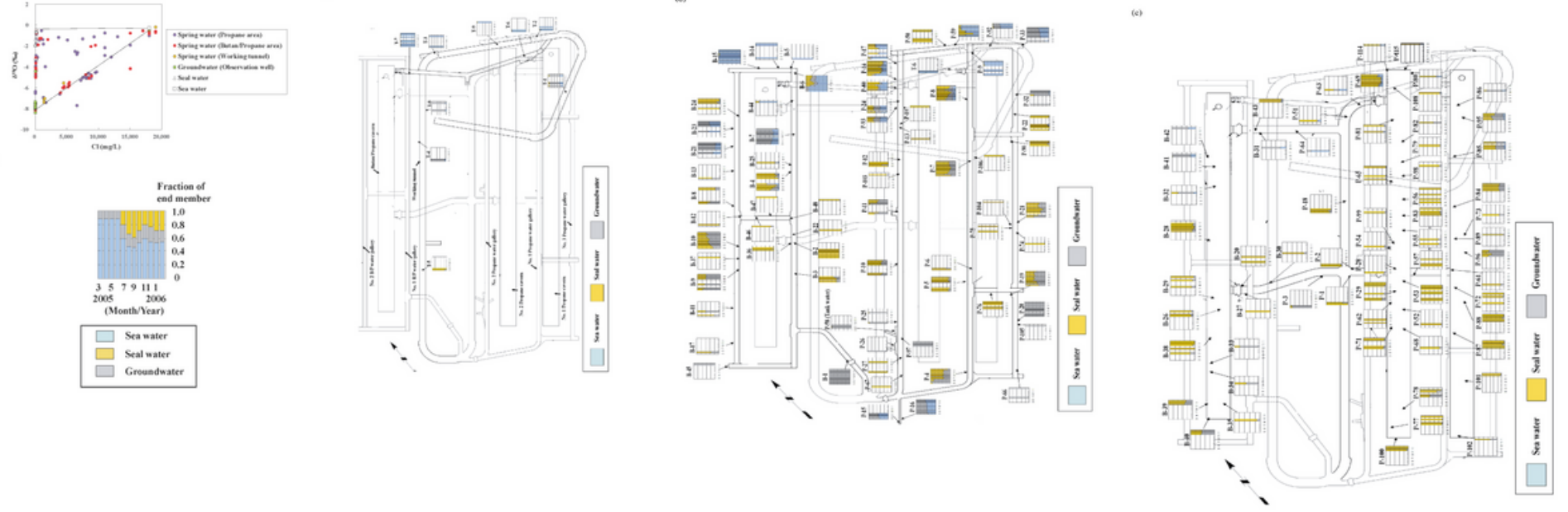

Figure 5

(a) $\delta 180$ vs. $\mathrm{Cl}$. (b) change of the percentage of the three end-members at the water sampling site (March 2005 to February 2006). End-member diagrams for (c) working tunnel, (d) water gallery, and (e) cavern. 
(a)

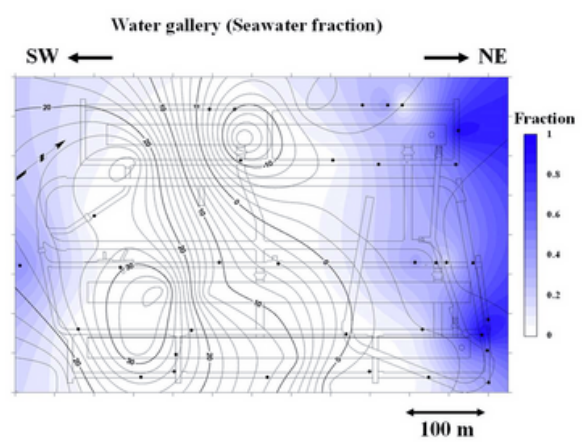

(b)

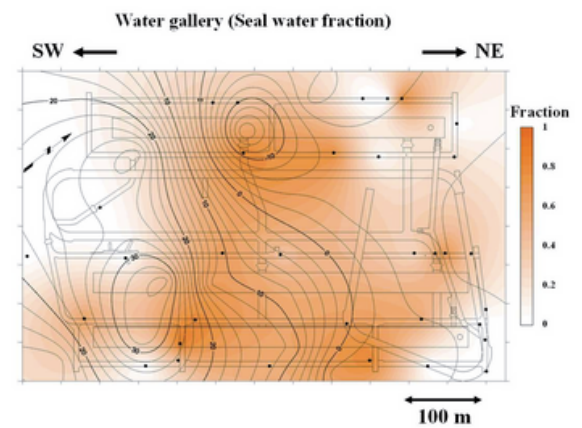

(c)

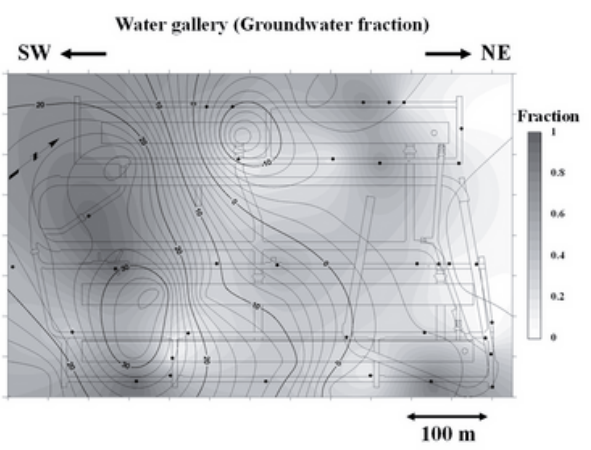

(d)

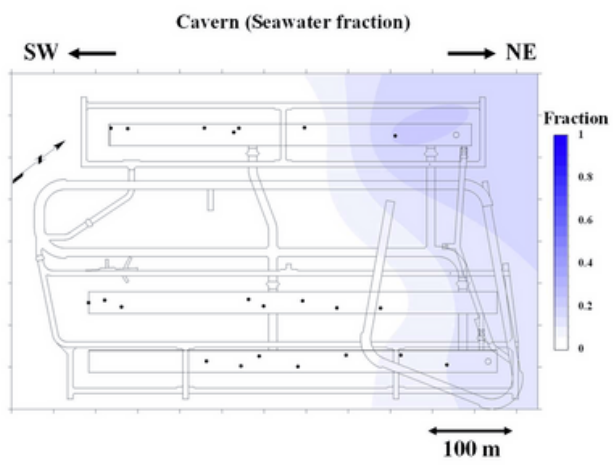

(e)

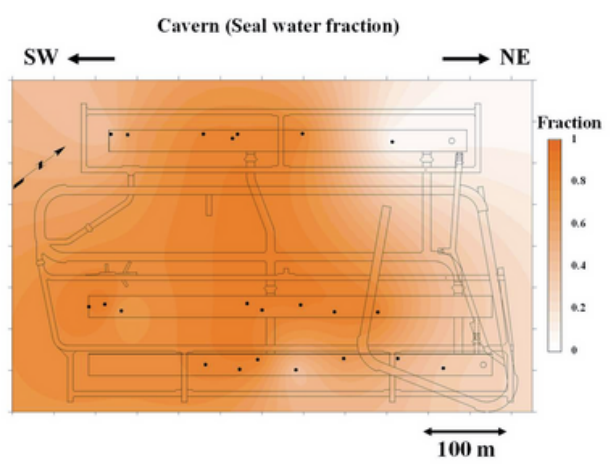

(f)

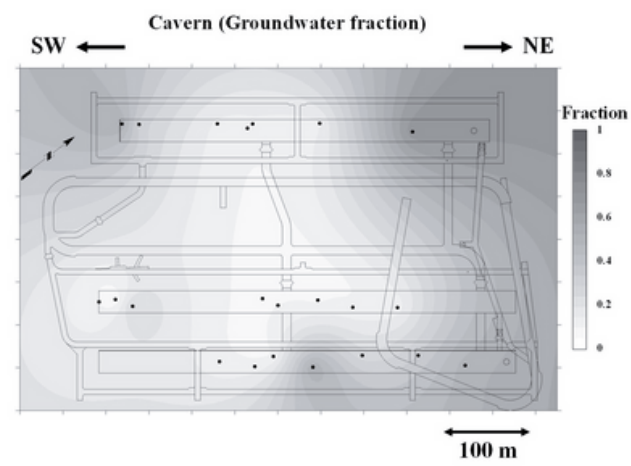

Figure 6

Distribution of three end-members, (a), (d) seawater, (b), (e) seal water, and (c), (f) groundwater, in the water gallery, (a)-(c) and the cavern, (d)-(f) in February 2006. 
(a)

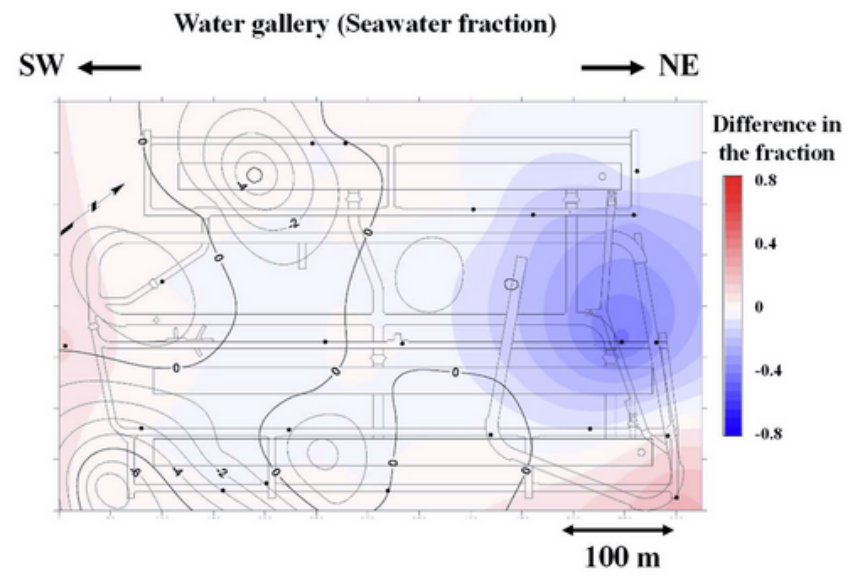

(b)

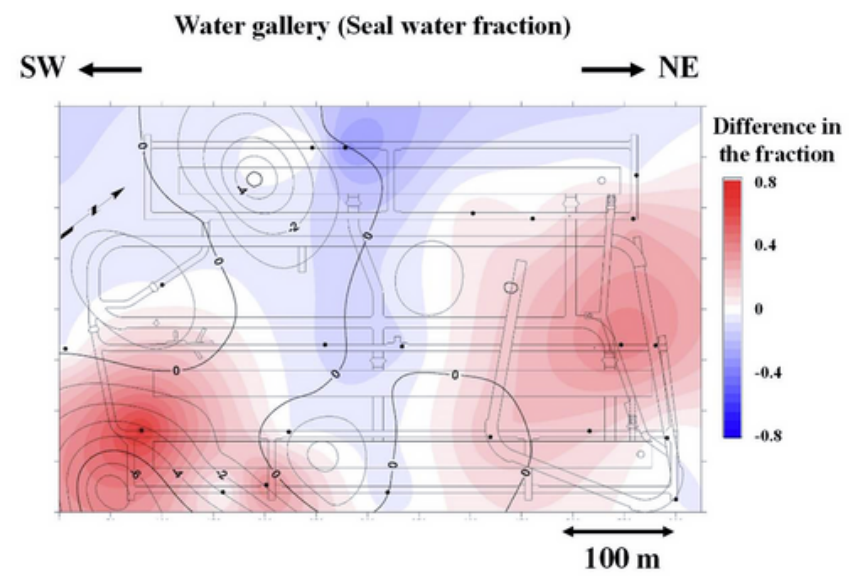

(c)

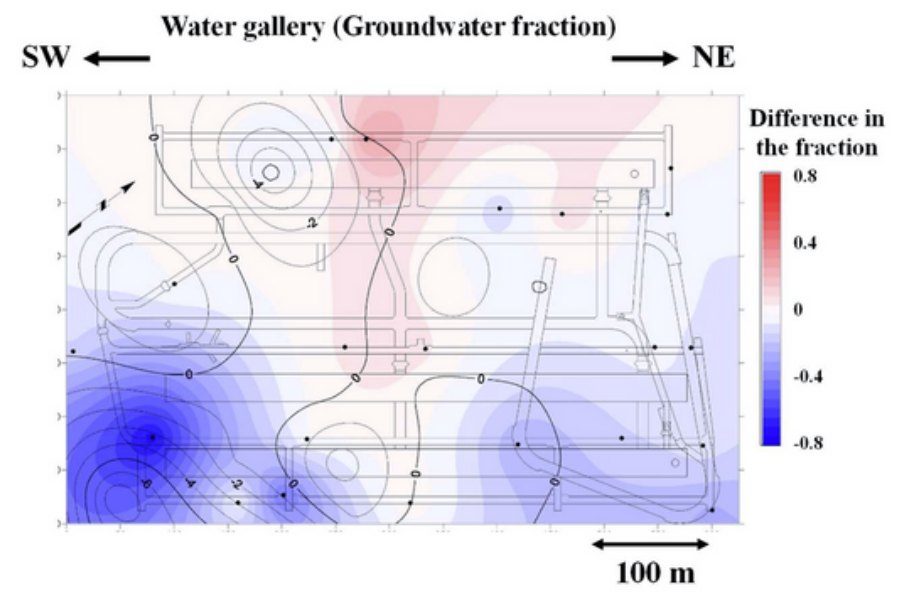

\section{Figure 7}

Difference of three end-members, (a) seawater, (b) seal water, and (c) groundwater, in water samples from the water gallery taken in May and December 2005. The red and blue sections indicate the percentage of end-members that increased and decreased, respectively, during the December sampling period. 


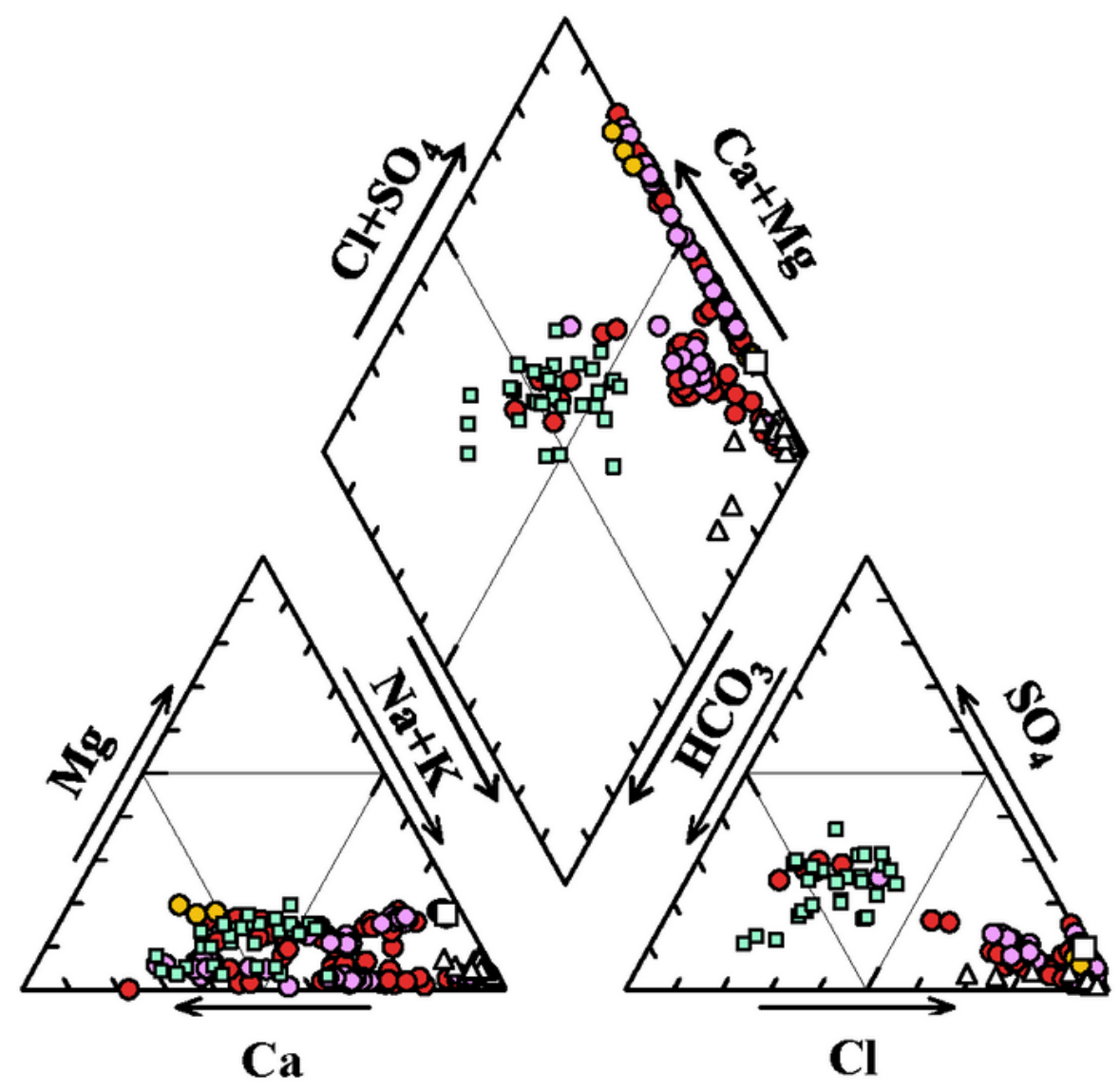

$\bigcirc$ Spring water (Propane area)

Spring water (Butan/Propane area)

Spring water (Working tunnel)

$\square$ Groundwater (Observation well)

$\triangle$ Seal water

$\square$ Sea water

Figure 8

Stiff diagram of water samples in the study area. 

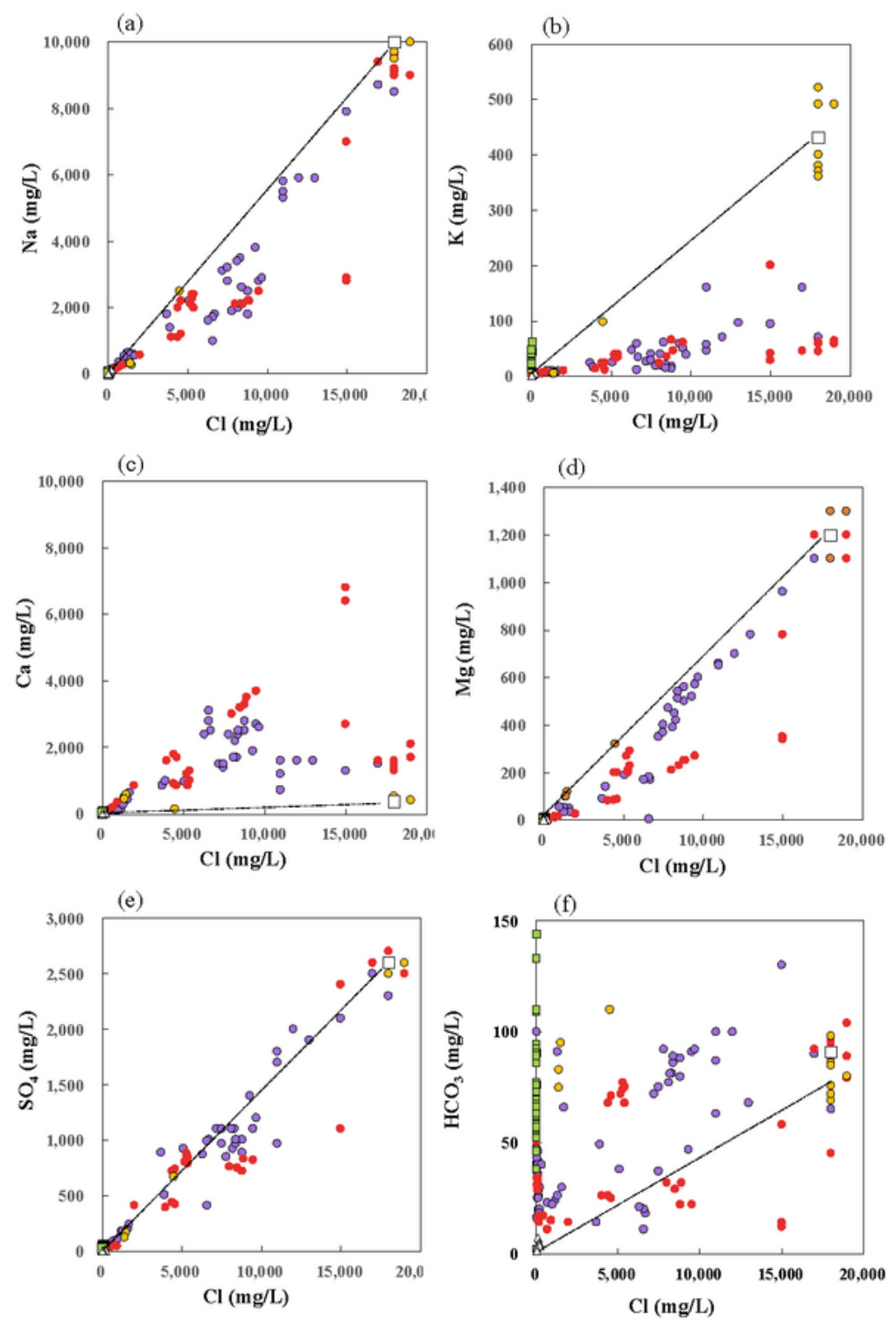

\begin{tabular}{|cl|}
\hline & Spring water (Propane area) \\
$\bigcirc$ & Spring water (Butan/Propane area) \\
$\bigcirc$ & Spring water (Working tunnel) \\
$\square$ & Spring water (Observation well) \\
$\Delta$ & Seal water \\
$\square$ & Sea water \\
\hline
\end{tabular}

\section{Figure 9}

Relationship between $\mathrm{Cl}$ and major chemical constituents of water samples in the study area. The broken line in the figure shows the mixing line between seawater and existing groundwater or seal water. 

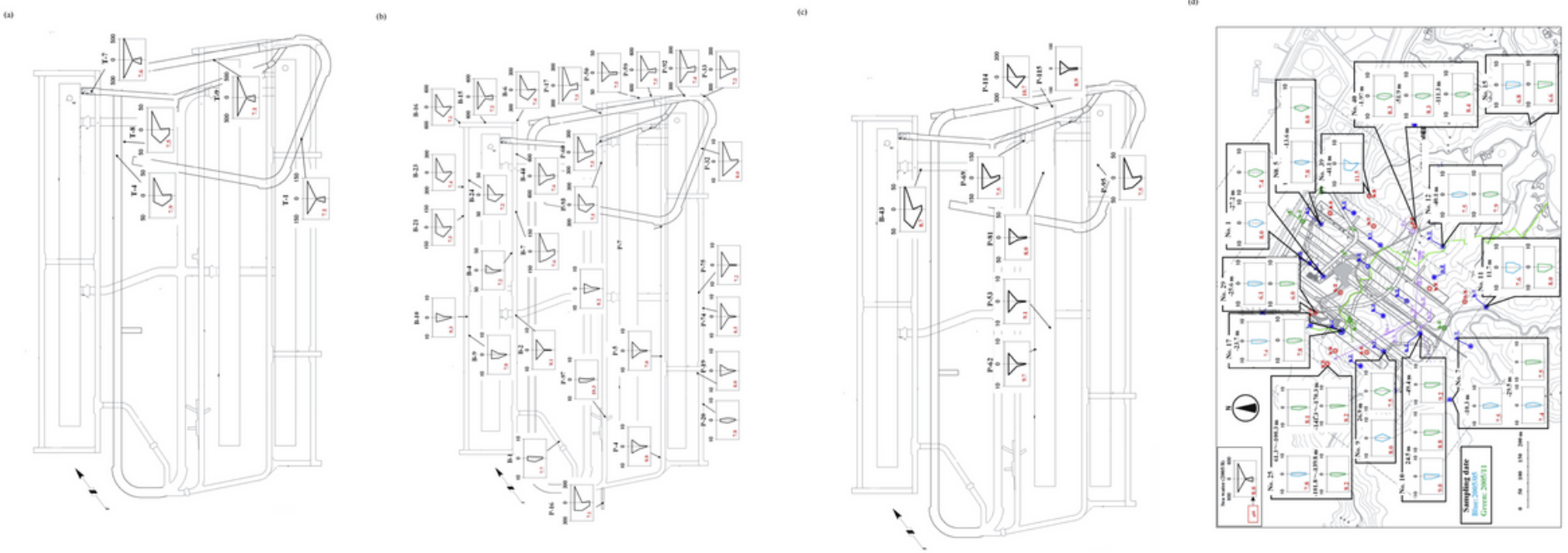

Figure 10

Piper diagram of water samples in (a) working tunnel, (b) water gallery, (c) cavern, and (d) observation well. Red in the figure indicates $\mathrm{pH}$.

\section{Supplementary Files}

This is a list of supplementary files associated with this preprint. Click to download.

- Supplementdata.docx 